\title{
Temporal patterns of active fire density and its relationship with a satellite fuel greenness index by vegetation type and region in Mexico during 2003-2014
}

Daniel Jose Vega-Nieva ${ }^{1}$ D, Maria Guadalupe Nava-Miranda², Eric Calleros-Flores², Pablito Marcelo López-Serrano ${ }^{2 *}$, Jaime Briseño-Reyes ${ }^{1}$, Carlos López-Sánchez', Jose Javier Corral-Rivas', Eusebio Montiel-Antuna', Maria Isabel Cruz-Lopez ${ }^{3}$, Rainer Ress ${ }^{3}$, Martin Cuahtle ${ }^{3}$, Ernesto Alvarado-Celestino ${ }^{4}$, Armando González-Cabán ${ }^{5}$, Citlali Cortes-Montaño ${ }^{1}$, Diego Pérez-Salicrup ${ }^{6}$, Enrique Jardel-Pelaez ${ }^{7}$, Enrique Jiménez ${ }^{8}$, Stefano Arellano-Pérez ${ }^{9}$, Juan Gabriel Álvarez-González ${ }^{9}$ and Ana Daria Ruiz-González ${ }^{9}$

\begin{abstract}
Background: Understanding the temporal patterns of fire occurrence and their relationships with fuel dryness is key to sound fire management, especially under increasing global warming. At present, no system for prediction of fire occurrence risk based on fuel dryness conditions is available in Mexico. As part of an ongoing national-scale project, we developed an operational fire risk mapping tool based on satellite and weather information.

Results: We demonstrated how differing monthly temporal trends in a fuel greenness index, dead ratio (DR), and fire density (FDI) can be clearly differentiated by vegetation type and region for the whole country, using MODIS satellite observations for the period 2003 to 2014. We tested linear and non-linear models, including temporal autocorrelation terms, for prediction of FDI from DR for a total of 28 combinations of vegetation types and regions. In addition, we developed seasonal autoregressive integrated moving average (ARIMA) models for forecasting DR values based on the last observed values. Most ARIMA models showed values of the adjusted coefficient of determination ( $R^{2}$ adj) above 0.7 to 0.8 , suggesting potential to forecast fuel dryness and fire occurrence risk conditions. The best fitted models explained more than $70 \%$ of the observed FDI variation in the relation between monthly DR and fire density.

Conclusion: These results suggest that there is potential for the DR index to be incorporated in future fire risk operational tools. However, some vegetation types and regions show lower correlations between DR and observed fire density, suggesting that other variables, such as distance and timing of agricultural burn, deserve attention in future studies.
\end{abstract}

Keywords: active fire density, ARIMA, fire occurrence risk, fuel greenness

\footnotetext{
* Correspondence: pmslopez@gmail.com; p_lopez@ujed.mx

${ }^{2}$ Instituto de Silvicultura e Industria de la madera, Universidad Juárez del

Estado de Durango, Boulevard del Guadiana 501, Ciudad Universitaria, Torre

de Investigación, 34120 Durango, Mexico

Full list of author information is available at the end of the article
} 


\section{Resumen}

Antecedentes: Una adecuada planificación del manejo del fuego requiere de la comprensión de los patrones temporales de humedad del combustible y su influencia en el riesgo de incendio, particularmente bajo un escenario de calentamiento global. En la actualidad en México no existe ningún sistema operacional para la predicción del riesgo de incendio en base al grado de estrés hídrico de los combustibles. Un proyecto de investigación nacional actualmente en funcionamiento, tiene como objetivo el desarrollo de un sistema operacional de riesgo y peligro de incendio en base a información meteorológica y de satélite para México. Este estudio pertenece al citado proyecto

Resultados: Se observaron en el país distintas tendencias temporales en un índice de estrés hídrico de los combustibles basado en imágenes MODIS, el índice "dead ratio" (DR), y en las tendencias temporales de un indice de densidad de incendios (FDI), en distintos tipos de vegetación y regiones del país. Se evaluaron varios modelos lineales y potenciales, incluyendo términos para la consideración de la autocorrelación temporal, para la predicción de la densidad de incendios a partir del índice DR para un total de 28 tipos de vegetación y regiones. Se desarrollaron además modelos estacionales autoregresivos de media móvil (ARIMA en inglés) para el pronóstico del índice DR a partir de los últimos valores observados. La mayoría de los modelos ARIMA desarrollados mostraron valores del coeficiente de determinación ajustado ( $R^{2}$ adj) por encima de 0.7 to 0.8 , sugiriendo potencial para ser empleados para un pronóstico del estrés hídrico de los combustibles y las condiciones de riesgo de ocurrencia de incendio. Con respecto a los modelos que relacionan los valores mensuales de DR con FDI, la mayoría de ellos explicaron más del $70 \%$ de la variabilidad observada en FDI.

Conclusiones: Los resultados sugirieron potencial del índice DR para ser incluido en futuras herramientas operacionales para determinar el riesgo de incendio. En algunos tipos de vegetación y regiones se obtuvieron correlaciones más reducidas entre el índice DR y los valores observados de densidad de incendios, sugiriendo que el papel de otras variables tales como la distancia y el patrón temporal de quemas agrícolas debería ser explorado en futuros estudios.

\section{Background}

Understanding the temporal patterns of fire occurrence risk-the chance that a fire might start and spread (Deeming et al. 1972; Hardy 2005) - and their relationships with fuel dryness is key to sound fire management, especially under increased global warming, which may result in increasing drought conditions and potentially increasing fire severity and frequency in some regions (e.g., Wotton et al. 2003; Gillett et al. 2004; Flannigan et al. 2006; Flannigan et al. 2009; Woolford et al. 2013).

Satellite sensors have been utilized in recent years to monitor fuel greenness and associated fire occurrence risk (Chuvieco et al. 2004; Lozano et al. 2007, 2008; Chuvieco et al. 2010; López et al. 2002; Yebra et al. 2008; Yebra et al. 2013). Some systems such as the Fire Potential Index (FPI; Burgan et al. 1998) have integrated satellite information by means of fuel greenness indices based on relative values of the Normalized Difference Vegetation Index (NDVI) for each vegetation type (Burgan and Hartford 1993, 1997; Burgan et al. 1996; Burgan et al. 1998), combined with daily $10 \mathrm{~h}$ fuel moisture content calculated from observations of weather stations (Fosberg and Deeming 1971) to map fuel greenness and associated fire risk. Such fire risk systems offer useful information for a sound decision-making in strategic fire management planning (e.g., Preisler et al. 2011; Mavsar et al. 2013; Rodríguez y Silva et al. 2014). These operational fire risk systems have largely been utilized in the United States of America (Burgan et al. 1998; Preisler and Westerling 2007; Preisler et al. 2009; Preisler et al. 2015) or on the European continent (Sebastian-Lopez et al. 2002), including Spain (Huesca et al. 2007; Huesca et al. 2009; Huesca et al. 2014).

In Mexico, Sepúlveda et al. (2001) tested the FPI system (Burgan et al. 1998) in the Baja California region, and Manzo-Delgado et al. (2004) and Manzo-Delgado et al. (2009) demonstrated the potential of the temporal evolution of NDVI-based indices as indicators of fuel drought and associated fire risk in central Mexico.

In addition to these pioneering studies, previous work on fire risk in Mexico has focused on the influence of climate and fuels at regional and local scales. Several studies analyzed climatic effects on fire regimes (e.g., Heyerdahl and Alvarado 2003; Fulé et al. 2005; Drury and Veblen 2008; Skinner et al. 2008; Návar-Cháidez and Lizárraga-Mendiola 2013). Others evaluated the role of weather variables such as precipitation or temperature (e.g., Avila-Flores et al. 2010a; Avila-Flores et al. 2010b; Carrillo García et al. 2012; Antonio and Ellis 2015), or weather-based indices (e.g., Villers-Ruiz et al. 2012) on 
fire occurrence risk, mainly at local or regional scales. Some local or regional studies also considered the influence of fuels on fire occurrence risk (e.g., Flores Garnica et al. 1990; Muñoz Robles et al. 2005; Wong González and Villers Ruiz 2007; Castañeda Rojas et al. 2015). Whereas previous research offers useful information specific to the scale of their regions of study, there is a need for studies analyzing fire risk and its relationships with fuel dryness spatial and temporal patterns at a national scale that cover the ample diversity of climatic and environmental conditions of Mexico (GonzálezCabán and Sandberg 1989; Cerano Paredes et al. 2010).

Studies analyzing the relationships of fire occurrence and fuel dryness at a national scale in Mexico are scarce (e.g., Zúñiga-Vásquez et al. 2017a; Pompa-García et al. 2018; Vega-Nieva et al. 2018), limiting our understanding of the effects of changing climatic conditions on fire risk, and preventing development of operational fire risk decision systems. This is in contrast with countries such as USA, Canada, or Brazil that have developed operational fire risk systems based on temporal and spatial quantification of fuel greenness and associated fire risk (e.g., Deeming et al. 1977; Van Wagner 1987; Burgan et al. 1997; Burgan et al. 1998; Preisler et al. 2004; Preisler et al. 2008; Preisler et al. 2011; Preisler et al. 2015; Setzer and Sismanoglu 2012; Riley et al. 2013). This lack of an operational fire risk system led the Forest National Commission (CONAFOR, in Spanish) and the National Research Agency (CONACYT, in Spanish) to fund the national scale project "Development of a Fire Danger System for Mexico." The main objective of the project is the development of an operational fire-risk mapping system based on satellite and weather information for Mexico (Vega-Nieva et al. 2019a; Vega-Nieva et al. 2019b). Vega-Nieva et al. (2018) focused on analyzing relationships between a satellite-based fuel greenness index, FPI (Burgan et al. 1998), and MODIS active fire registers in the period 2011 to 2015. The models developed in that study were limited to observed fuel greenness values, but further work is required for fire risk forecasting. The present study focused on understanding temporal patterns of active fire density by vegetation type and region in Mexico for the period 2003-2014, explored its relationships with a MODIS-based fuel greenness index, and developed forecast models for the prediction of the fuel greenness index for the following month based on previously observed values. The specific objectives of the study were:

1) To quantify monthly temporal trends of a MODIS satellite-based fuel greenness index, dead ratio (DR), and the temporal trends of active fire density (FD) by vegetation type and region in Mexico.
2) To test regression models, including temporal autocorrelation of residuals, for prediction of monthly FD by vegetation type and region from monthly DR values in Mexico.

3) To develop autoregressive integrated moving average (ARIMA) models that can be utilized for forecasting DR based on the last observed values of this index.

\section{Methods \\ Study area}

Because of the national scope of the work, the area of study was the Mexican Republic. Figure 1 shows the vegetation types present in the country according to the National Institute of Geography and Statistics (INEGI, in Spanish) land use map (INEGI Land Use Map Series V, 1:25000 http://www.inegi.org.mx/geo/ contenidos/recnat/usosuelo/).

Based on previous analysis of active fire temporal trends in the country (Vega-Nieva et al. 2018), we reclassified vegetation types into the following seven categories: Agriculture (AG), Arborous Secondary Vegetation (ARBSV), Deciduous Tropical Forest (DTROPF), Pastureland (PAS), Perennial Tropical Forest (PTROPF), Shrubby Secondary Vegetation (SHSV), and Temperate Forest (TFOR).

Given the well-documented variations in fire regimes seasonality in the country (e.g., Rodríguez-Trejo et al. 2008; Yocom et al. 2010; Yocom and Fulé 2012; Yocom et al. 2014; Jardel et al. 2014), four geographical regions-Northwest (NW), Northeast (NE), Center (C), and South (S)-were established (Fig. 1). The region definitions were based on the potential fire regimes zoning for Mexico (Jardel et al. 2014), as well as vegetation types and climatic zones (Holdridge 1996), together with a visual observation of the temporal and spatial patterns of clustering in fire hotspots for the period of study. The seven vegetation types defined above were present in all four regions, resulting in a total of 28 combinations of vegetation types and regions to be modeled.

\section{MODIS monthly active fire and NDVI data}

Considering the availability of MODIS active fire information for Mexico, we selected the period of 2003 to 2014 for our study. We compiled monthly composites of MODIS active fire detections for the 12 years of the study period from CONABIO (http://incendios1.conabio.gob.mx/ ). Active fires were obtained based on the Contextual Fire Detection Algorithm for MODIS (Giglio et al. 2003). Active fires data were filtered by CONABIO following the protocol described by Cruz-López (2007). This data filtering included the consideration of specific thresholds for brightness temperature (Cruz-López 2007), and the use of additional masks such as NDVI, vegetation, or stable light masks to minimize false detections, as 


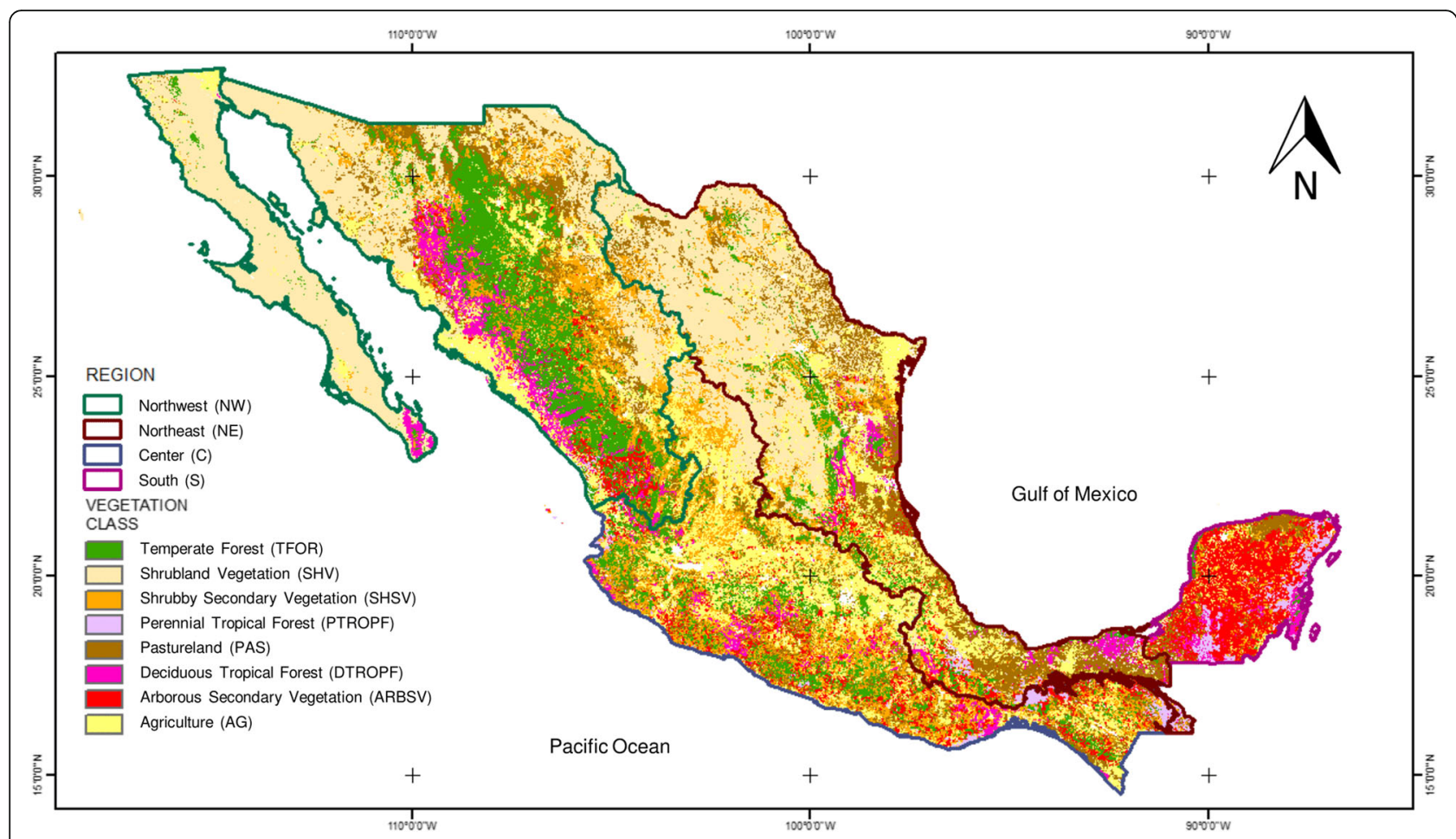

Fig. 1 Map of vegetation types and regions in Mexico that were considered in the analysis, for the period 2003 to 2014

described by Cruz-López (2007) and Vega-Nieva et al. (2018). Monthly NDVI composite images with a spatial resolution of $1 \mathrm{~km} \times 1 \mathrm{~km}$ (MODIS product MOD13A3) from the study period were downloaded from http://modis. gsfc.nasa.gov/data/dataprod/mod13.php

\section{Dead ratio calculation}

Following Burgan et al. (1998), the following DR index was calculated:

$$
D R=100-L R,
$$

where $D R=$ dead ratio and $L R=$ live ratio.

Dead ratio is an empirical index representing the fraction of fuel that is not alive, reaching 100 in a fuel that is completely cured with no live biomass, and with lower values representing fuels with a higher fraction of live biomass. Its calculation is based on relative greenness values and maximum live ratios following Burgan et al. (1998) equations 2 to 4 :

$$
L R=\frac{R G \times L R_{\max }}{100},
$$

where $R G$ is relative greenness, and calculated as:

$$
R G=\frac{N D V I_{0}-N D V I_{\min }}{N D V I_{\max }-N D V I_{\min }} \times 100,
$$

where $N D V I_{0}$ is the observed NDVI for each pixel at every month, and $N D V I_{\min }$ and $N D V I_{\max }$ are the minimum and maximum NDVI values for each pixel, respectively.

$L R_{\max }$ is the maximum live ratio, calculated following equation 4 based on Burgan et al. (1998):

$$
L R_{\max }=\frac{35+40\left(N D V I_{\max }-125\right)}{255-125} .
$$

The values 125 and 255 are the absolute minimum and maximum NDVI values observed for Mexico. Maximum and minimum NDVI values for each pixel and absolute minimum and maximum NDVI values were calculated by considering all of the NDVI monthly images for the period 2003 to 2014. DR values were calculated for each monthly NDVI image in the period of study, and mean DR value for each monthly image was calculated using Cell Statistics in ArcGIS 10.3 (ESRI 2011).

\section{Fire Density Index}

For each of the 28 vegetation types and regions considered, monthly Fire Density (FD) was calculated 
by dividing the number of fires in the area by the surface $\left(\mathrm{km}^{2}\right)$ of the vegetation and region considered. Monthly FD values for each vegetation type and region were scaled to a Fire Density Index (FDI) as follows:

$$
F D I=\frac{\text { Number of active fires }}{\text { Surface }\left(\mathrm{km}^{2}\right) \times 5000} .
$$

The FDI index is defined so that an FD of 0.01 active fires $\mathrm{km}^{-2}$ (e.g., 1 fire per $100 \mathrm{~km}^{2}$ ) is equivalent to an FDI value of 50. Accordingly, an FD of 2 active fires per $100 \mathrm{~km}^{2}$ is equivalent to an FDI value of 100 , which might be considered an indicator of a high active fire density.

\section{Modeling monthly FDI from DR}

Except for Agriculture, fire season concentrated on the period December to June for all vegetation types considered. Agriculture showed an earlier start of fire season, caused by agricultural burnings, which usually take place very early in the dry season (Martínez-Torres et al. 2016). Consequently, all land uses, except for agriculture, were modeled for the period December to June, and Agriculture was modeled for the whole year.

\section{Model formulation and selection}

We fitted linear and non-linear (power) models for prediction of FDI from DR for each vegetation type and region, following:

$$
F D I=a-b D R,
$$

and

$$
F D I=a D R^{\mathrm{b}},
$$

where $a$ and $b$ are model coefficients, FDI is Fire Density Index (Equation 5), and $D R$ is dead ratio (Equation 1).

To further assess whether the models were different among different months or groups of months, the nonlinear extra sum of squares method was used (Bates and Watts 1988: 103-104). This method requires the fitting of full and reduced models and has frequently been applied to assess whether separate models are necessary for different species or different geographic regions (e.g., Huang et al. 2000; Zhang et al. 2002; Corral-Rivas et al. 2004; Castedo et al. 2005; Corral-Rivas et al. 2007). In this paper, the reduced model corresponds to the same set of global parameters for all months, as shown in Equations 6 and 7. The full models correspond to different sets of global parameters for different months or group of months, which are obtained by expanding each global parameter by including an associated parameter and a dummy variable to differentiate the months or groups of months. For example, the expansion of a global parameter $b$ of a linear model (Equation 6 for the reduced model) for every month can be written as:

$$
b_{1} d_{1}+b_{2} d_{2}+\ldots+b_{12} d_{12}
$$

where $b_{1}$ through $b_{12}$ are the associated parameters of the full model, and $d_{1}$ through $d_{12}$ are the dummy categorical variables for considering the months, which are defined as follows: $d_{1}=1$ if month = January, otherwise $d_{1}=0 ; \ldots ; d_{12}=1$ if month $=$ December, otherwise $d_{12}=0$.

We considered all possible combinations of months for analysis, using either linear or non-linear (power) formulations. For example, the expansion of a global parameter $b$ of a linear model with a separated coefficient for the group of months 1 to 5 (January to May) and 6 to 12 (June to December) can be written as:

$$
b_{1-5} d_{1-5}+b_{6-12} d_{6-12},
$$

where $b_{1-5}$ and $b_{6-12}$ are the associated parameters of the full model for the corresponding group of months 1 to 5 and 6 to 12 , respectively, and $d_{1-5}$ and $d_{6-12}$ are the dummy categorical variables for identifying each corresponding group of months, defined as follows: $d_{1-5}=1$ if month = January to May, otherwise $d_{1-5}=0 ; d_{6-12}=$ 1 if month $=$ June to December, otherwise $d_{6-12}=0$.

The appropriate test statistic for comparing full and reduced models used the following expression:

$$
F=\frac{\frac{S S E_{\mathrm{R}}-S S E_{\mathrm{F}}}{d f_{\mathrm{R}}-d f_{\mathrm{F}}}}{\frac{S S E_{\mathrm{F}}}{d f_{\mathrm{F}}}}
$$

where $S S E_{\mathrm{R}}$ is the error sum of squares of the reduced model, $S S E_{\mathrm{F}}$ is the error sum of squares of the full model, and $d f_{\mathrm{R}}$ and $d f_{\mathrm{F}}$ are the degrees of freedom of the full and reduced models, respectively. The non-linear extra sum of squares follows an $F$-distribution.

If the above $F$-test results revealed that there was no difference among the models for different months, a composite model fitted on the combined data was all that was needed. If the $F$-test results showed that there were differences among models $(P<0.05)$, further tests were needed to evaluate whether the differences were caused by as few as two months, or as many as all of the months. For instance, full models for all combinations of grouped months (1 to 12 grouped months for Agriculture and 1 to 6 grouped months for the remaining vegetation types) were compared with their corresponding reduced model using the $F$-test. Only when an insignificant $F$-value $(P>0.05)$ was obtained 
could the models for these two group of months be considered similar and combined.

We selected candidate models for which the grouped coefficients were significantly different as detected by the $F$-test. These candidate models were further evaluated by the following goodness of fit statistics: adjusted coefficient of determination $\left(R^{2}\right)$, root mean squared error (RMSE), and Akaike's Information Criterion (AIC), calculated as follows:

$$
\begin{aligned}
& R_{\mathrm{adj}}^{2}=1-\frac{(n-1) \Sigma\left(y_{\mathrm{i}}-\widehat{y}_{\mathrm{i}}\right)^{2}}{(n-p) \Sigma\left(y_{\mathrm{i}}-\bar{y}\right)^{2}}, \\
& R M S E=\sqrt{\frac{\sum\left(y_{\mathrm{i}}-\widehat{y}_{\mathrm{i}}\right)^{2}}{n-p}},
\end{aligned}
$$

and

$$
A I C=n \times I n \sigma^{2}+2 \times l-n \times I n \sigma^{2}+2 \times l
$$

where: $y_{\mathrm{i}}$ and $\hat{y}_{\mathrm{i}}$ are the observed and estimated values of the dependent variable, respectively; $\bar{y}$ is the average value of the dependent variable; $n$ is the total number of observations used to fit the model; $p$ is the number of model parameters; $l=p+1$, and $\hat{\sigma}^{2}$ is the estimator of the error variance of the model, obtained as follows:

$$
\sigma^{2}=\frac{\sum_{\mathrm{i}=1}^{\mathrm{n}}\left(y_{i}-\widehat{y}_{\mathrm{i}}\right)^{2}}{n}
$$

\section{Autocorrelation}

Because the structure of the data includes consecutive observations of FDI, autocorrelation within the residuals of each vegetation type and region might be expected, which would violate the assumption of independent error terms. In order to account for this temporal autocorrelation, the adjustment was performed in two stages. First we adjusted models without accounting for the correlation between consecutive observations. We then examined presence of autocorrelation based on the visual inspection of plots of residuals against residuals from previous observations for each combination of vegetation type and region. Based on the observed autocorrelation at time lags of order $k$, we included a modified $k$-order autoregressive error structure, which accounted for the time lag between consecutive observations in the models for each combination of vegetation type and region. Error terms were consequently expanded as follows:

$$
e_{\mathrm{i}}=\sum_{\mathrm{k}=1}^{\mathrm{x}} I_{\mathrm{k}} \rho_{\mathrm{k}}^{\mathrm{h}_{\mathrm{i}}-\mathrm{h}_{\mathrm{i}-\mathrm{k}}} e_{\mathrm{i}-\mathrm{k}}+\varepsilon_{\mathrm{i}},
$$

where $I_{\mathrm{k}}=1$ for $i>k$ and $I_{\mathrm{k}}=0$ for $i=k, \rho_{\mathrm{k}}$ is the $k$ order continuous autoregressive parameter to be estimated, and $h_{\mathrm{i}}-h_{\mathrm{i}-\mathrm{k}}$ is the time lag length (months) separating the $i$ th from the $i$ th $-k$ observations, $e_{\mathrm{i}-\mathrm{k}}$ is the ordinary residual at previous month $i-k$ (i.e., the difference between the observed and the estimated FDI at month $i$ ) for each combination of vegetation type and region.

The order $k$ of the modified error structure was selected based on the plots of residuals against lag residuals. Models were fitted by use of the Model Procedure of SAS/ETS (SAS Institute Inc. 2009).

The error terms were included linearly into the models. For example, for Equation 6, the model with autocorrelated error can be written as:

$$
F D I=a+b \times D R+e_{\mathrm{i}}
$$

where $a$ and $b$ are model coefficients; FDI is Fire Density Index (Equation 5); $D R$ is dead ratio (Equation 1); and $e_{\mathrm{i}}$ is the error term for the month $i$, expanded following Equation 15.

\section{Autoregressive integrated moving average (ARIMA) modeling of DR}

We tested the fitting of seasonal AutoRegressive (AR) Integrated (I) Moving Average (MA) models (ARIMA) for forecasting the DR time series of each vegetation type and region. Seasonal ARIMAs are commonly utilized in the remote sensing domain due to the highly significant seasonal component usually associated with remote sensing time series (e.g., Fernández-Manso et al. 2011; Huesca et al. 2014).

The seasonal ARIMA model incorporates both nonseasonal and seasonal factors in a multiplicative model. One shorthand notation for the model is:

$$
\operatorname{ARIMA}(\text { ar }, \text { dif }, m a) \times(\text { sar }, \text { sdif }, \text { sma }) S,
$$

where ar $=$ non-seasonal AR lag order, dif = nonseasonal differencing, $m a=$ non-seasonal MA lag order, $s a r$ = seasonal AR lag order, sdif = seasonal differencing, sma = seasonal MA lag order, and $S=$ time span of repeating seasonal pattern.

Seasonal ARIMA models were fitted using the auto.arima command within the library forecasting in R (Hyndman 2016; R Core Team 2016). The Standard AIC selection criterion (Hamilton 1994) was applied to select the most suitable model. The individual 
and joint significance of the model parameters was assessed by means of the Student's $t$ and $F$ tests.

We examined autocorrelation by plotting regular and partial autocorrelation functions (ACF and PACF, respectively) for both the variable $\mathrm{DR}$ to be adjusted and the residuals obtained by the ARIMA models. PACF and ACF plots of both DR and model residuals were obtained using the library forecasting in $R$ (Hyndman 2016; R Core Team 2016). We selected models of the lowest AIC for which no autocorrelation in the residuals was present as observed in Partial Autocorrelation Function (PACF) and Autocorrelation Function (ACF) plots.

\section{Results}

\section{Observed temporal trends of monthly DR and FDI}

Figure 2 (captures at high resolution included as annexes) shows the observed temporal trends of the monthly mean DR values together with monthly FDI values observed for each one of the 28 combinations of vegetation types and regions for the 12-year period considered in the study.

\section{Observed DR temporal trends by vegetation types and regions}

For vegetation types, the highest $\mathrm{DR}$ values were observed in Agriculture and Pasture, and the lower DR values were found for all Tropical Forests, whereas Temperate Forests showed intermediate DR values. For most vegetation types, a regional gradient was observed, with the highest DR values found in the NW region and lowest values in the $\mathrm{S}$, with $\mathrm{C}$ and $\mathrm{NE}$ regions showing intermediate values. During the first months of the year, all vegetation types and regions showed increasing DR values. The patterns of DR increase in these earlier months varied largely between vegetation types and regions. In general, the increase of DR occurred earlier for the NW region compared to the $\mathrm{C}$ and $\mathrm{S}$ regions. The rates of DR decrease, likely caused by the occurrence of precipitation, also varied largely by vegetation type and region. The decrease of DR occurred earliest at the $\mathrm{C}$ and $\mathrm{S}$ regions for most of the vegetation types, often peaking in the months of April and May, and decreasing in the following months. In the NW region, the decrease of DR tended to occur later than the other regions, with NE showing intermediate values.

\section{Observed FDI trends by vegetation types and regions}

FDI values varied largely between vegetation types and regions. The highest FDI values were observed for Agriculture, Pasture, and Shrubby Secondary Vegetation in the $S$ region, with values $>500$ (equivalent to a fire density of $>10$ fire hotspots per $100 \mathrm{~km}^{2}$ ).

The $\mathrm{C}$ region also showed high FDI values for most of the vegetation types, with maximum FDI values $>250$ ( $>5$ fire hotspots per $100 \mathrm{~km}^{2}$ ) for most land uses.

In the NW region, the highest FDI values were found for Temperate Forest, with FDI values $>300$ (equivalent to $>6$ fires per $100 \mathrm{~km}^{2}$ ). In the NE region, observed FDI for Temperate Forest was lower than in the NW region, with observed FDI values $<50 \quad(<1$ fire hotspot per $100 \mathrm{~km}^{2}$ ) for most of the years.

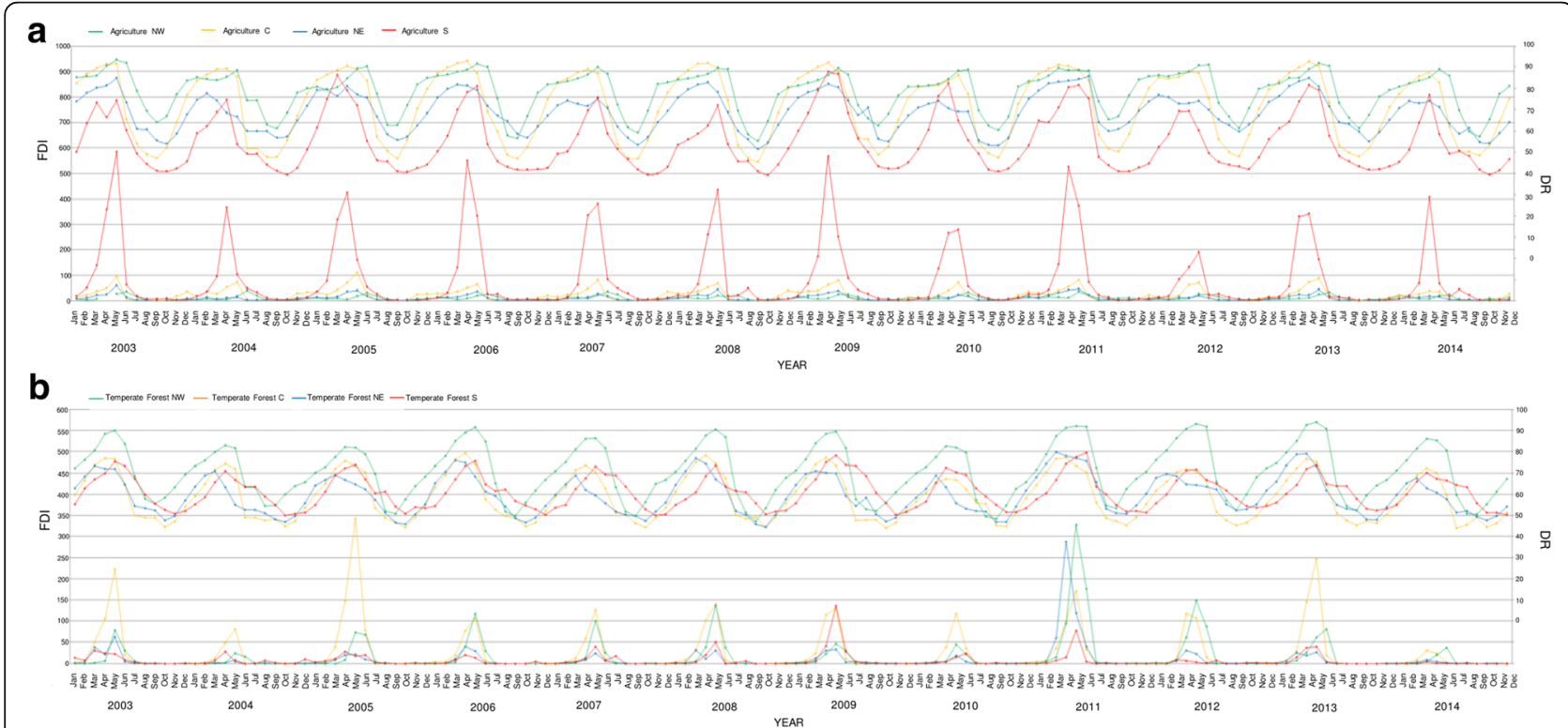

Fig. 2 Observed monthly Dead Ratio (DR; upper lines, right axis) and Fire Density Index values (FDl; lower lines, left axis) by vegetation type and region in Mexico for (a) Agriculture and (b) Temperate Forest, in the period 2003 to 2014. NW: Northwest region, NE: Northeast region, C: Center region, and S: South region. High resolution figures for all vegetation types are included as Additional files 1, 2, and 3 
Arborous and Shrubby Secondary Vegetation showed high FDI values for all of the regions, with $C$ and $S$ regions reaching values above 100 in all years, and with values above 50 for NW and NE regions.

Regarding Tropical Forests, high FDI values, $>100$ and even $>200$, were found in the driest years for Deciduous Tropical Forests (DTROPF) in the four regions. Observed FDI values were generally two or three times higher than corresponding values for Perennial Tropical Forests (PTROPF) in the NW, NE, and $\mathrm{S}$ regions (Fig. 2). In the $C$ region, in spite of lower DR conditions in PTROPF compared to DTROPF as expected in a wetter ecosystem, observed FDI values were high in both ecosystem types.

\section{Models relating monthly FDI with DR by vegetation type and region}

Based on the $F$-tests and the evaluation of their goodness of fit statistics, we selected the models shown in Table 1 as the best candidate models for each vegetation type and region. Fitted model coefficients for the selected best models are shown in Table 2. Nonlinear (power) models described the data better than linear models for all vegetation types and regions. Both linear and power-reduced models-those with common parameters for all months-(i.e., Equations 7 and 8) resulted in $\mathrm{R}^{2}$ values lower than 0.5 for all land uses, with the exception of Pasture from the NW region and Deciduous Tropical Forests of the $\mathrm{S}$ region that could be modeled with a reduced non-linear model with all months grouped (Equation 7; Table 2). For the remaining vegetation types, the probability of finding a critical value greater than the calculated $F$ statistic was lower than 0.01 with full models. There were, therefore, differences among the models for month or group of months.

Equations 7 and 18 through 26, with grouped coefficients for the earlier months (December to February, March, or April) best fitted the data for non-agricultural vegetation types. Most models showed separated coefficients for the peak months April and May, varying by vegetation type and region. In the case of Agriculture (modeled for the 12 months), months of September to March or April could be grouped, suggesting a constant relationship of DR to FDI at the start of the fire season, with latter months (May, June, and, in some regions, also April) having higher fire occurrence as noted by higher coefficient values for those latter months (Table 2: Equations 27 to 29).

Predicted and observed FDI values for each vegetation type and region are shown in Fig. 3. Goodness of fit statistics for the best fit models are shown in Table 2 . The selected equations showed good fits for several vegetation types and regions, with 13 of 28 models showing adjusted $R^{2}$ values higher than $0.8,11$ models in the range of 0.7 to 0.8 , and four models (those for Temperate Forests and Tropical Forests of the NE region and Pasture of the NW) with adjusted $R^{2}$ values ranging from 0.65 to 0.7 .

Table 1 Selected models for prediction of monthly Fire Density Index from Dead Ratio values for Mexico, for the period 2003 to 2014. Veg: vegetation type; AG: Agriculture; All but AG: all vegetation types except Agriculture; Eq. $n$ : equation number. FDI: monthly Fire Density Index; DR: monthly Dead Ratio; $a$ and $b$ are model coefficients; $d_{j}$ : dummy variable for identifying month or group of months $i$, with value $=1$ for the identified month or group of months $i$ and value $=0$ for the remaining months. Numbers in coefficients and in model description correspond to months or groups of months, with 12: December, 1: January, 2: February, 3: March, 4: April, 5: May, 6: June, 7: July, 8: August, 9: September, 10: October, 11: November. Consecutive month groups are indicated with an en dash (-) and nonconsecutive month groups indicated with a low line ( _ ). For example, in Eq. 20, termed 12-3, 4_6, 5, there are three groups of months with distinct coefficients: months 12 to 3 together, months 4 and 6 together, and month 5 separately

\begin{tabular}{|c|c|c|c|}
\hline Veg & Eq. $n$ & Month groups & Equation \\
\hline \multirow[t]{10}{*}{ All but $A G$} & 7 & All months grouped & $F D I=a D R^{b}$ \\
\hline & 18 & $12-4 \_6,5$ & $F D I=\left(d_{12-4 \_} a_{12-4 \_} D R+d_{5} a_{5} D R\right)^{b}$ \\
\hline & 19 & $12-3,4-6$ & $F D I=\left(d_{12-3} a_{12-3} D R+d_{4-6} a_{4-6} D R\right)^{b}$ \\
\hline & 20 & $12-3,4 \_6,5$ & $F D I=\left(d_{12-3} a_{12-3} D R+d_{4 \_6} a_{4 \_6} D R+d_{5} a_{5} D R\right)^{b}$ \\
\hline & 21 & $12-3,4-5,6$ & $F D I=\left(d_{12-3} a_{12-3} D R+d_{4-5} a_{4-5} D R+d_{6} a_{6} D R\right)^{b}$ \\
\hline & 22 & $12-3 \_6,4-5$ & $F D I=\left(d_{12-3 \_6} a_{12-3-6} D R+d_{4-5} a_{4-5} D R\right)^{b}$ \\
\hline & 23 & $12-3 \_6,4,5$ & $F D I=\left(d_{12-3 \_} 6 a_{12-3 \_} 6 R+d_{4} a_{4} D R+d_{5} a_{5} D R\right)^{b}$ \\
\hline & 24 & $12-2,3,4 \_6,5$ & $F D I=\left(d_{12-2} a_{12-2} D R+d_{3} a_{3} D R+d_{4 \_} a_{4 \_} D R+d_{5} a_{5} D R\right)^{b}$ \\
\hline & 25 & $12-2,3 \_6,4,5$ & $F D I=\left(d_{12-2} a_{12-2} D R+d_{3 \_} a_{3 \_} D R+d_{4} a_{4} D R+d_{5} a_{5} D R\right)^{b}$ \\
\hline & 26 & $12-2 \_6,3,4-5$ & $F D I=\left(d_{12-2 \_} 6 a_{12-2 \_} D R+d_{3} a_{3} D R+d_{4-5} a_{4-5} D R\right)^{b}$ \\
\hline \multirow[t]{3}{*}{$A G$} & 27 & $9-4,5-8$ & $F D I=\left(d_{9-4} a_{9-4} D R+d_{5-8} a_{5-8} D R\right)^{b}$ \\
\hline & 28 & $9-3,4-6,7-8$ & $F D I=\left(d_{9-3} a_{9-3} D R+d_{4-6} a_{4-6} D R+d_{7-8} a_{7-8} D R\right)^{b}$ \\
\hline & 29 & $9-3 \_7-8,4,5-6$ & $F D I=\left(d_{9-3 \_7-8} a_{9-3-7-8} D R+d_{4} a_{4} D R+d_{5-6} a_{5-6} D R\right)^{\mathrm{b}}$ \\
\hline
\end{tabular}




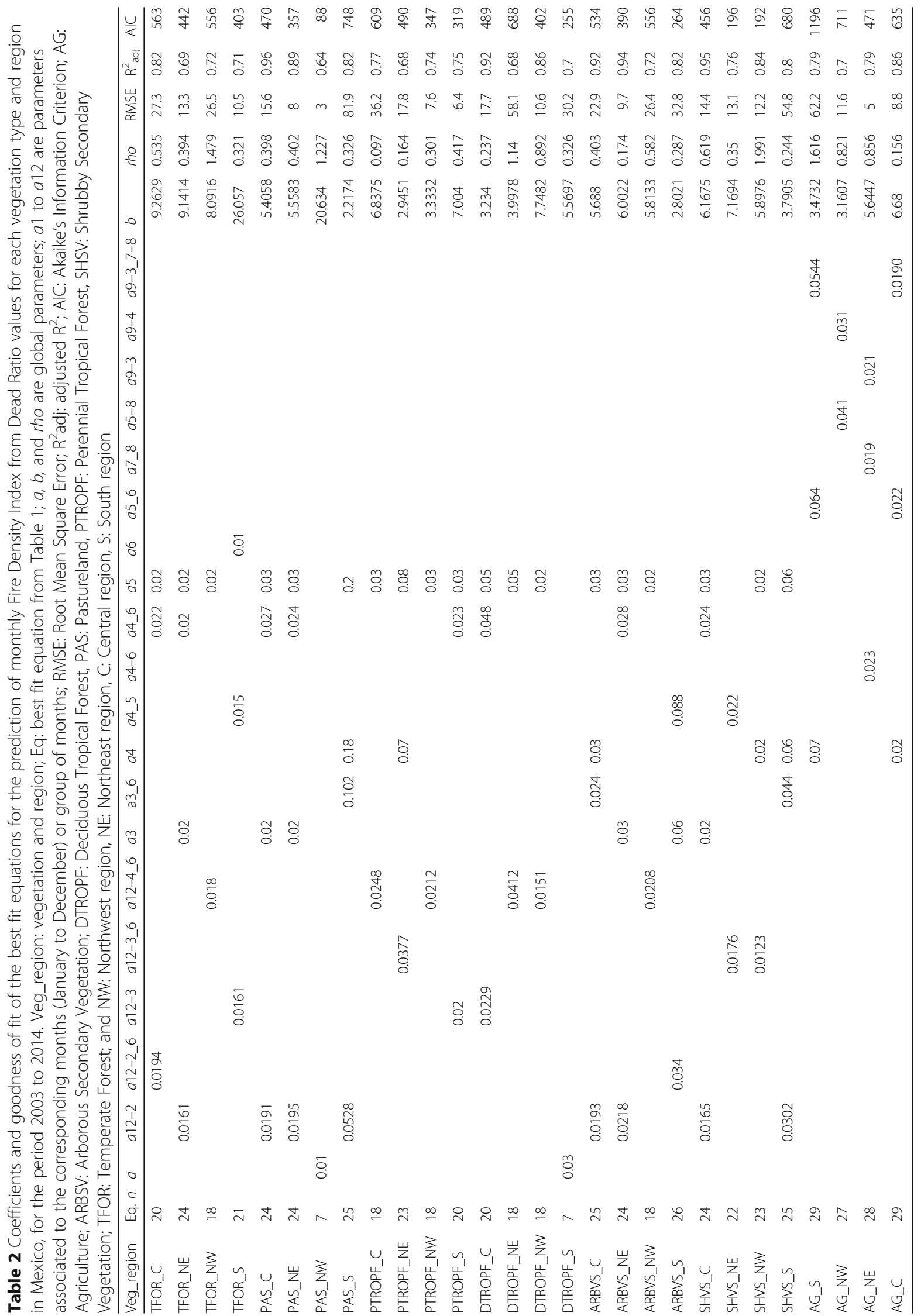




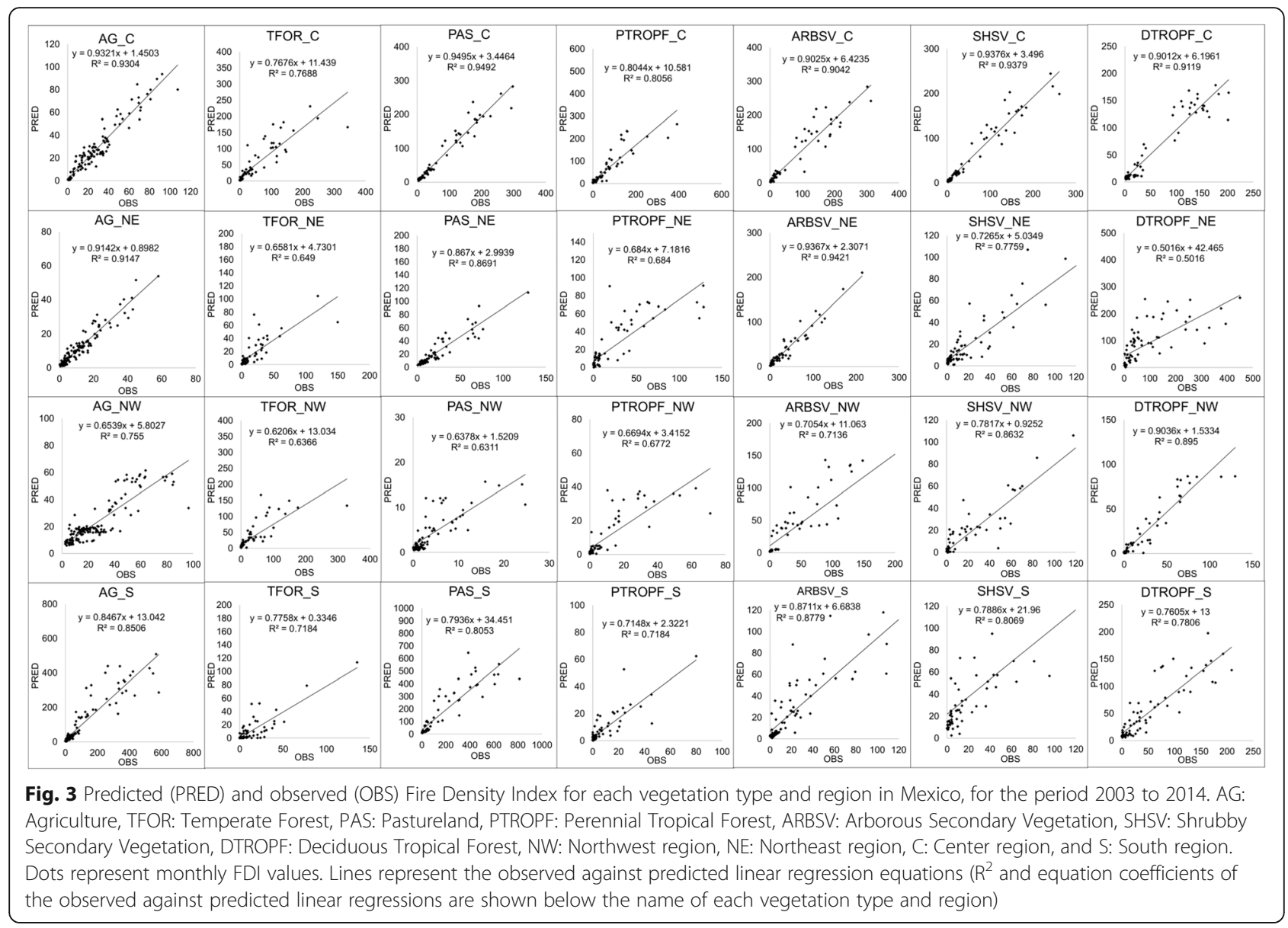

\section{Autocorrelation in FDI models}

A visual examination of the residuals at time $i$ against the corresponding residuals at previous months $i-k$, showed that residuals were correlated at time lag $k=1$ (i.e., with the previous month). No correlation was observed for the residuals for time lags $k$ greater than 1 month for any vegetation type. Table 2 shows the rho parameter included in the models to account for residuals temporal autocorrelation.

\section{Autoregressive integrated moving average (ARIMA) modeling of DR}

The best fit ARIMA models and goodness of fit coefficients are shown in Table 3. The best fit seasonal ARIMA models showed good adjusted $R^{2}$ values, with 14 models showing $R^{2}$ values higher than 0.8 , nine models with adjusted $\mathrm{R}^{2}$ values of 0.7 to 0.8 , and five models (SHSV_S, PAS_S, ARBSV_S, PAS_NE, PTROPF_ $\mathrm{NE}$, and PTROPF_S) with adjusted $\mathrm{R}^{2}$ values of 0.6 to 0.7. RMSE values ranged from $<15$ for 13 models, $<25$ for a total of 24 models, and the remaining four models ranging between 25 and 35 (DTROPF_NE, AG_S, PAS_ $\mathrm{S}$, and DTROPF_NW).
The order of the non-seasonal autoregressive coefficients (ar) ranged from 1 to 6 months, often corresponding to the correlation lags suggested by the Partial Autocorrelation Function (PACF) and Autocorrelation Function (ACF) plots of DR. No integrated coefficients (dif and sdif) were obtained for any model, as expected due to the absence of differencing in the variable to be modeled. Some of the best fit models included moving average $(m a)$ coefficients with a lag of one to two months, and seasonal autoregressive (sar) and moving average (sma) coefficients with lags of one to three previous months. For all models, we plotted ACF and PACF of the variable DR to be adjusted, and also of the residuals after adjustment, to inspect the presence of partial or absolute correlation at any time lag after adjustment. Figure 4 shows an example of ACF and PACF plots of DR and of the best fit ARMA model residual. ACF and PACF plots for all vegetation types are included as annexes. For all vegetation types, correlations at time lags ranging from 1 to 6 months were visible in the PACF and ACF plots of the DR variable to be modeled. This correlation was removed in the residuals of the best fit models, with PACF and ACF values below the level for significant correlation at all time lags (Fig. 4 and annexes). 


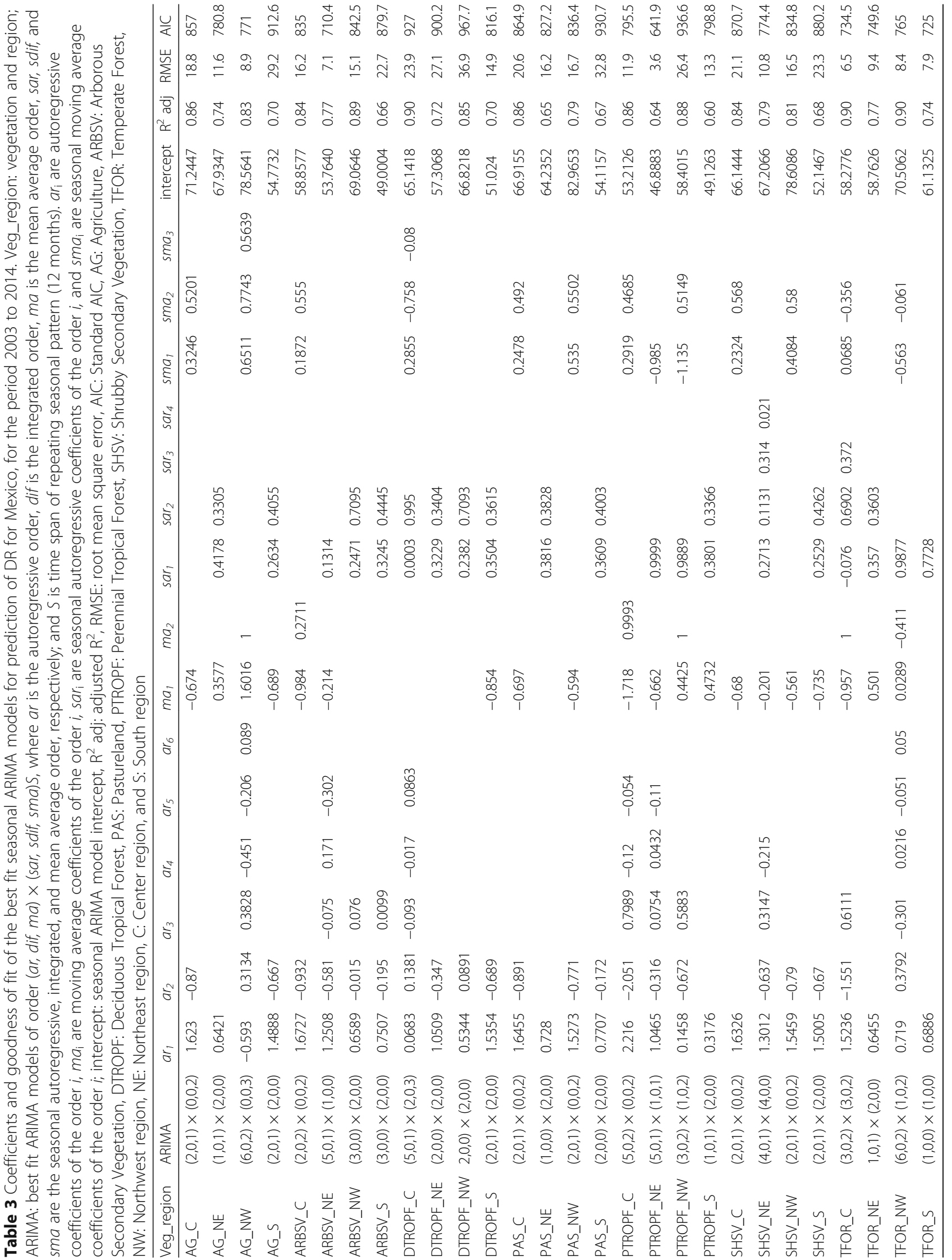




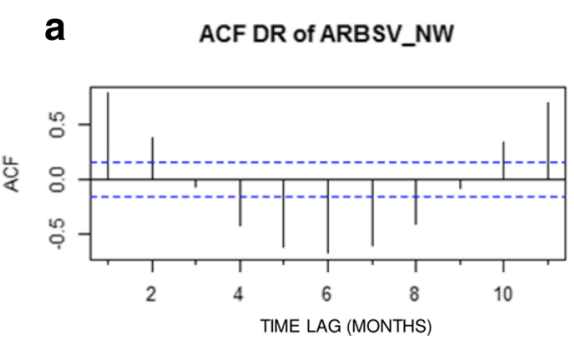

C

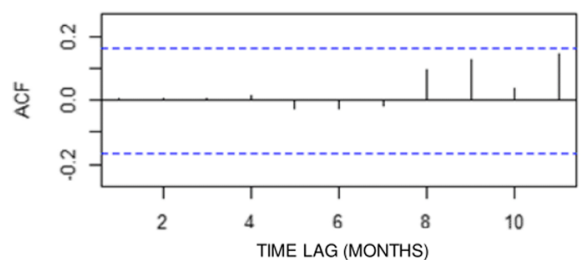

b PACF DR of ARBSV_NW

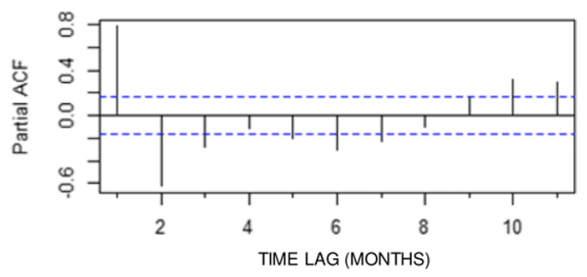

d

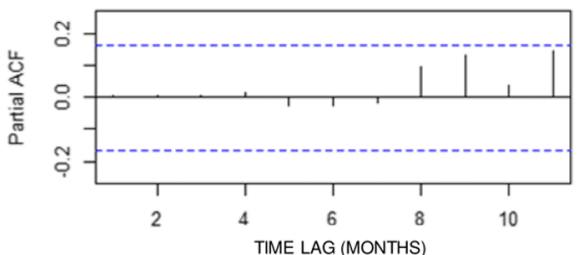

$\mathbf{e}$

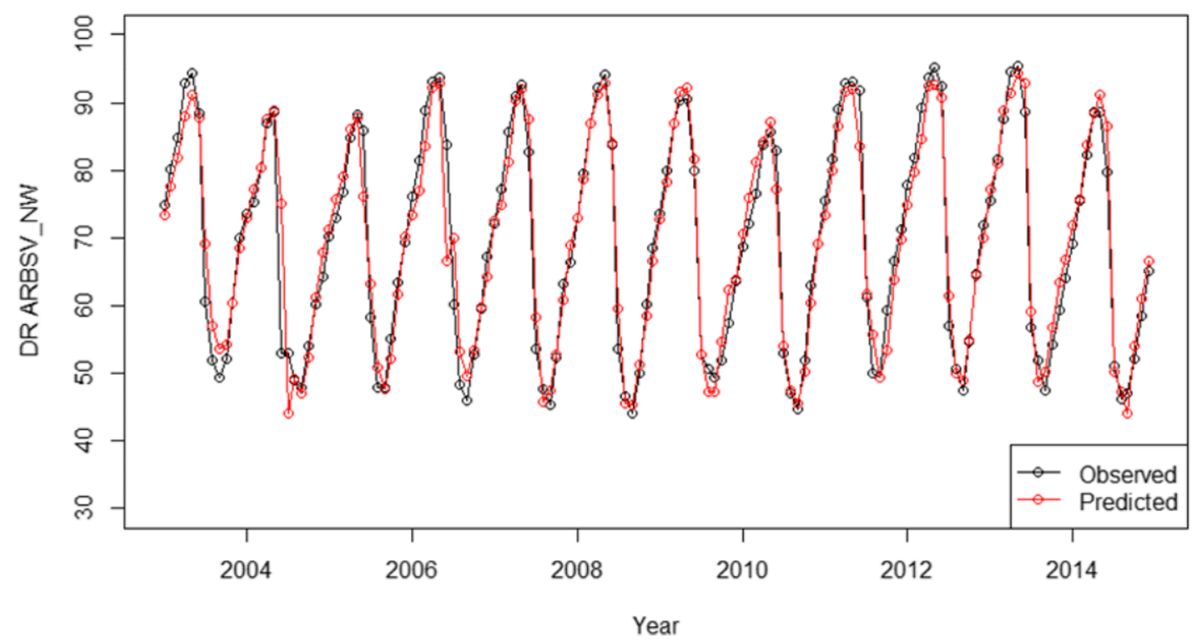

Fig. 4 (a, b) Example of plots of regular and partial autocorrelation functions (ACF and PACF) of the Dead Ratio (DR) data of Arborous Secondary Vegetation of the NW region (ARBSV_NW), and (c, $\mathbf{d})$ of the residuals of the modeled DR with the best fit ARIMA model, and (e) of observed and predicted DR for ARBSV_NW utilizing the best fit seasonal ARMA model for Mexico, for the period 2003 to 2014. Lines in blue (a to d) mark the limits for significant autocorrelation. Observed data in (e) are shown in black, predicted data in red

\section{Mapping predicted fire occurrence risk}

We produced maps of predicted active fire ignition density from DR based on the best fit models for each vegetation type. Figure 5 shows an example of predicted active fire ignition density maps for the fire season months of March to June for two contrasting years: 2011, an extremely dry year with a large fire occurrence, and 2010, a more moderate fire year, representative of average fire occurrence conditions. The year of 2011 represents an extreme of fire occurrence records in Mexico, with an affected total area of 956405 ha (Zúñiga-Vásquez et al. 2017a), and the largest recorded fire event in the history of the country (Pompa-García et al. 2018).
It can be seen that the different fuel drought conditions resulted in very contrasting FDI predictions between the two years. In the year 2011, predicted FDI was high to extreme for the months of April and May for the NW and NE regions, corresponding to a very high hotspot density observed in those two regions and contrasting with lower predicted FDI and observed hotspot density for the same months in the year 2010 . Fire risk in the $C$ region was also higher in 2011, with higher predicted and observed fire density in the months of March to May. In the S region, drought and associated FDI were also higher in the year 2011, particularly in the months of May and June, corresponding with a higher observed hotspot density. 


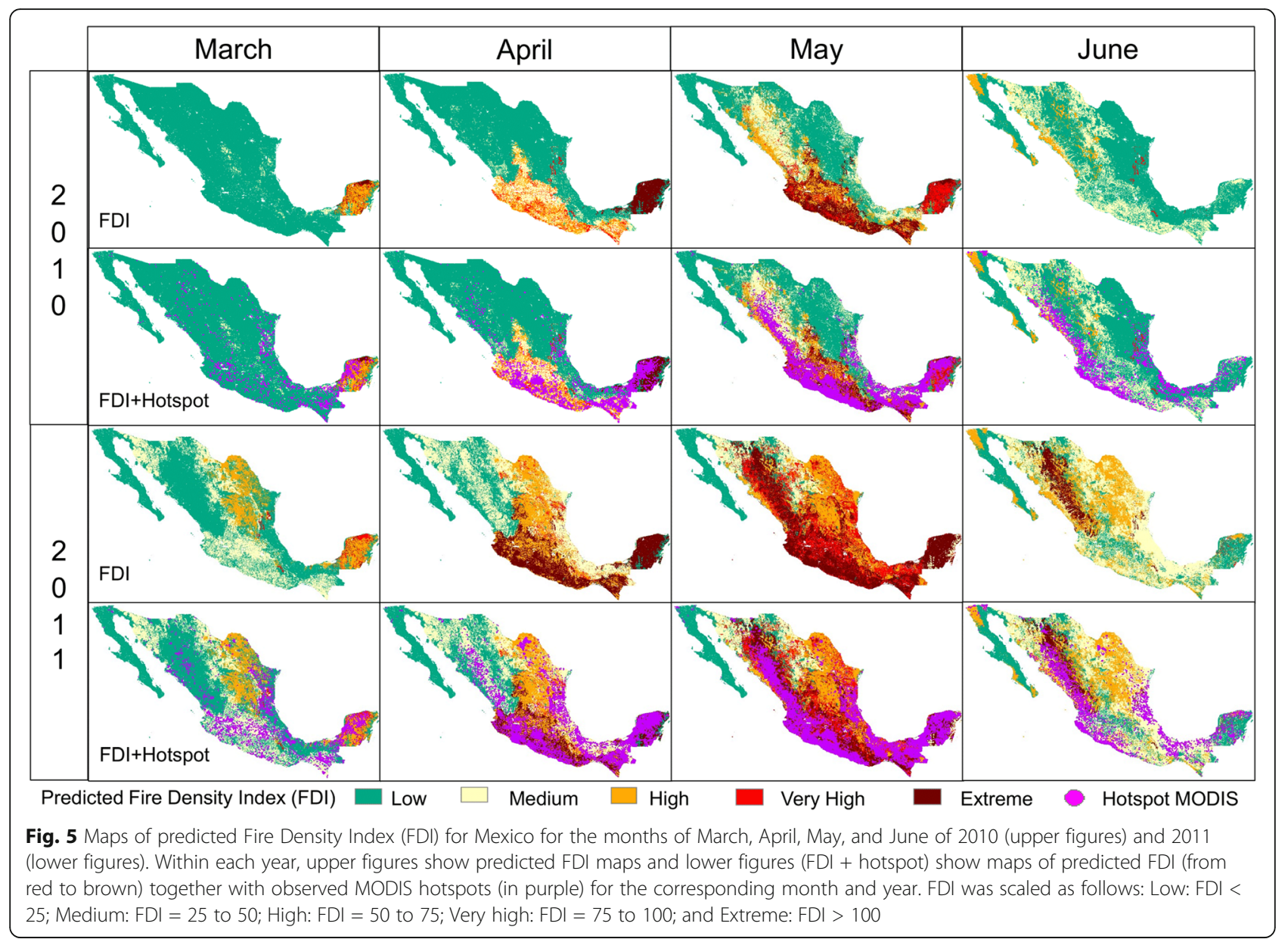

\section{Discussion}

\section{Observed DR temporal trends by vegetation types and regions}

The variations in DR trends between vegetation types suggest a sensitivity of this index to variations in fuel dryness of different ecosystem types. The highest DR values were observed for Pasture and Agriculture, while the lowest DR values were measured in more humid ecosystems such as perennial tropical forests. The relative greenness component of the index was designed to normalize the index value between land types. However, by multiplying relative greenness by a maximum live ratio, which depends on the maximum NDVI (Burgan et al. 1998), the DR index takes into account variability due to type of vegetation. Different types of vegetation have different seasonal trends of drying and wetting, which is reflected in their NDVI temporal trends (e.g., Yebra et al. 2008). For example, Manzo-Delgado et al. (2009) recorded distinct NDVI trends for grasslands, temperate forests, tropical forests, and xerophytic scrublands in central Mexico and included vegetation type in their logistic model for predicting fire occurrence probability in their region of study.
DR values also showed sensitivity to the dryness between regions, with a consistent gradient from the more arid NW to the more humid S, present for most vegetation types. The NW region has a marked rain season starting in June to July, whereas in the tropical S, precipitation is more constant throughout the year. Different timing of precipitation between regions might explain the different dates observed for the DR decrease. This decrease was observed generally one month later in the NW region compared to the $\mathrm{C}$ and $\mathrm{S}$ regions, probably caused by a later start of the rain season in the NW region, in the months of June and July.

Interestingly, the relationships between DR and FDI trends varied by vegetation type and region. For example, for many land uses such as Agriculture, Pasture or Temperate Forests, the increase of DR (Fig. 2: upper lines) occurred earlier in the NW region compared to a later occurrence of this DR increase in the $\mathrm{C}$ or $\mathrm{S}$ regions. Looking at the FDI patterns for those land uses (Fig. 2: lower lines), the start of the fire season, as noted by an FDI increase, occurred earlier in $\mathrm{C}$ and $\mathrm{S}$ regions than in the NW region, suggesting that either a longer accumulated drought is required in the NW region for 
fires to start, or human patterns of ignition might differ between these regions. Earlier start of fire season might be related to human calendar of agricultural activities in these regions, where the occurrence of forest fires has been documented to be largely related to escaped agricultural burns (e.g., Román-Cuesta et al. 2004; RománCuesta and Martínez 2006; Rodríguez-Trejo et al. 2008; Rodríguez-Trejo et al. 2011; Carrillo García et al. 2012).

These differences suggest that the relationships between DR trends and fire occurrence might be specific for each type of vegetation and region.

\section{Observed FDI trends by vegetation types and regions}

The high FDI values observed in the $S$ or $C$ region for Agriculture and Pasture were not surprising, because these territories are characterized by frequent slash-andburn agricultural activities and clearing of forest for expansion of agriculture, which result in frequent fires (e.g., Rodríguez-Trejo and Fulé 2003; Román-Cuesta et al. 2004; Román-Cuesta and Martínez 2006; Rodríguez-Trejo et al. 2008; Rodríguez-Trejo et al. 2011; Carrillo García et al. 2012; Ibarra-Montoya and HuertaMartínez 2016). These high ignition densities in the $C$ region are consistent with those observed in previous studies of active fire density for the period 2011 to 2015 (Vega-Nieva et al. 2018), as well as with the fire suppression registers spatial analysis from Pompa-García et al. (2018) and Zúñiga-Vásquez et al. (2017b) in Mexico.

In the NW region, the highest FDI values were observed for Temperate Forests, agreeing with previous studies in the region (e.g., Avila-Flores et al. 2010a; Avila-Flores et al. 2010b; Pérez-Verdin et al. 2013a; 2013b; Pérez-Verdin et al. 2014; Pompa-García and Hernández González 2012), that found that most of the fires in Durango State occurred on conifer and hardwood temperate forest.

Lower FDI values were observed in the Temperate Forests of the NE region, which, as discussed above, was probably caused by higher precipitation in this region and an earlier DR decrease caused by an earlier start of the rain season compared to the NW region. However, in years of extreme conditions such as 2011 under La Niña ENSO (El Niño-Southern Oscillation) event, high fire occurrence was found in the forests of the NE region, as noted by an FDI value of $>250$ ( $>5$ fires per $100 \mathrm{~km}^{2}$ ) (Fig. 2). This extreme-conditions year corresponds to unprecedented area burned, with the largest fire in Mexico's history-317000 ha-occurring in northern Coahuila (CONAFOR 2011).

There is no agreement in the literature about the role of El Niño and La Niña ENSO events in the NE region of Mexico (e.g., Yocom et al. 2010; Yocom and Fulé 2012; Yocom et al. 2014), located at the transition between the areas affected by drought under the influence of El Niño (S) and those affected by La Niña (NW) (e.g., Román-Cuesta et al. 2003; Seager et al. 2007; Seager et al. 2009; Yocom et al. 2010). Meanwhile, the DR trends observed in 2011 for the NE region Temperate Forests, peaking at a value of 80 in April 2011, as opposed to DR values of less than 70 in most of the other years and corresponding with low FDI values of $<50$ (Fig. 2), seem to suggest that extreme drought conditions were present in the NE forests under 2011 La Niña events. The extreme fire occurrence observed for that region for this period of time seems to suggest that DR might be a potentially useful indicator for detecting extreme drought and associated fire risk conditions in this region caused by ENSO events, although a longer time frame will be required for assessing its performance under future El Niño and La Niña events.

Arborous Secondary Vegetation showed high FDI values in the four regions, suggesting that this might be a fire-prone vegetation type. The likely cause being the high available fuel load that may be expected in this type of ecosystem, constituted by young trees with low crown height combined with high loads of surface fuels. These fuel characteristics result in a potentially high risk of torching and potentially extreme fire behavior, as opposed to a lower risk of torching and lower severity fire regime expected in more mature forest types such as old-growth temperate forests (e.g., Morfín Ríos et al. 2007; Cortés Montaño et al. 2012; Jardel et al. 2014).

Perennial Tropical Forests (PTROPF) showed lower FDI values compared to Deciduous Tropical Forests (DTROPF) in the NW, NE, and $S$ regions. This is expected in this evergreen ecosystem with high moisture conditions for most of the year, compared to drier conditions found in the DTROPF, as noted by lower DR values in these latter ecosystems (Fig. 2). In the $C$ region, both Perennial Tropical Forest and Tropical Forest showed high FDI values, in spite of lower DR values in PTROPF, as expected in this more humid ecosystem. The high FDI values observed in this type of ecosystem with high moisture content are very likely caused by adjacent agricultural burns escaping into forest lands. The majority of the Perennial Tropical Forest area in this region can be found in the state of Chiapas, located in the vicinity of agricultural land (Fig. 1). In this state, reports of agricultural burns and escaped fires from agriculture to both Temperate Forest and Perennial Forest are frequent (e.g., Román-Cuesta et al. 2004; Román-Cuesta and Martínez 2006). Both Deciduous Tropical Forest and Perennial Tropical Forest in Mexico have historically been ecosystems with a low frequency of fires (e.g., Rodríguez-Trejo et al. 2008; Jardel et al. 2014). However, several studies have noted that this historical fire regime has been recently 
altered because of human activities that have resulted in the introduction of fire on ecosystems historically not adapted to it, with potentially adverse effects on post-fire regeneration of these fire-sensitive ecosystems (e.g., Rodríguez-Trejo 2008, 2015).

\section{Models relating monthly FDI with DR by vegetation type and region}

For all of the vegetation types and regions studied, the relationship of FDI with monthly DR was better described with nonlinear than with linear models, suggesting that the relationship of DR with fire occurrence is not linearly proportional (e.g., fire occurrence risk increased very rapidly with increasing DR). Different patterns of FDI and DR relationships were observed for different vegetation types and regions, agreeing with observations that point to a variety of fire regimes resulting from combinations of climatology and fuel types in the country (e.g., Rodríguez-Trejo 2008, 2015; Morfín Ríos et al. 2007; Morfin Rios et al. 2012; Jardel et al. 2014; Vega-Nieva et al. 2018).

The results suggested that significantly different models are required for prediction of FDI from DR for most vegetation types for different groups of months. Thus, derived model coefficients for months and groups of months may offer information about the patterns of timing of fire season and their relationships with DR patterns in different vegetation types and regions.

Models with grouped coefficients for December to February (Tables 1 and 2: Equations 24 through 26) suggest an earlier start of the fire season, with March having a higher coefficient value compared to the three previous months. This was observed for Pasture in all regions but NW, Shrubby Secondary Vegetation in the S and C regions, Arborous Secondary Vegetation in the $\mathrm{C}$ and $\mathrm{NE}$ regions, and Temperate Forest in the NE region. The timing of agricultural burning in the $\mathrm{C}, \mathrm{S}$, and $\mathrm{NE}$ regions might be behind this phenomenon, with observed fires in Shrubby Secondary Vegetation and Arborous Secondary Vegetation starting as early as March being possibly related to escaped agricultural burns in these regions.

In the $\mathrm{C}$ region, grouped coefficients from December to March were observed for Temperate Forest and seasonally dry Deciduous Tropical Forest (Table 1: Equation 20), suggesting a latter start of fire in the month of April. For Perennial Tropical Forests in the $\mathrm{C}$ region, grouped coefficients were obtained from December to April (Table 1: Equation 18), suggesting that, in this region, at least one more month of prolonged dry conditions might be required for fire to start in these more humid tropical forest ecosystems.

For the NW region, grouped coefficients from December to March were obtained for Shrubby Secondary Vegetation
(Table 1: Equation 23) - one month later than for the $\mathrm{S}$ and $\mathrm{C}$ regions-with all remaining vegetation types having grouped coefficients from December to April and separated coefficients for the month of May (Equations 18 and 27), also suggesting a later fire start for these vegetation types compared to other regions, particularly $\mathrm{S}$ and $\mathrm{C}$. These results seem to suggest that, in the NW region, most vegetation types might be achieving the required conditions of accumulated drought for fire to occur one or two months later compared to other regions such as $\mathrm{C}$ or $\mathrm{S}$, which might be linked to the different timing of precipitation between these regions, or to different patterns in the timing of human-caused ignitions such as agricultural activities.

Most models had good fit, except Tropical Forests models that had a more limited performance. This is likely caused by a lower sensitivity of FDI to DR in this more humid ecosystem, where fires might spread from agricultural lands that are already dry and burned under nonoptimum conditions as discussed above. Several studies have pointed to agricultural extension and the proximity to agricultural areas as significant factors explaining fire occurrence in Tropical Forests (e.g., Rodríguez-Trejo and Fulé 2003; Román-Cuesta and Martínez 2006; RománCuesta and Martínez 2006; Rodríguez-Trejo et al. 2008; Rodríguez-Trejo et al. 2011). This highlights the need to further understand the role of anthropogenic factors of fire occurrence in these ecosystems where fire is progressively introduced as a consequence of human activities.

Although the model coefficients obtained may account indirectly for some of the variations in ignitions pattern caused by human activity patterns, future spatial analysis should focus on the explicit consideration of anthropogenic variables such as the interface of forests and agriculture or the accessibility due to proximity to roads and populations as potentially relevant variables in explaining fire occurrence in Mexico.

Another additional limitation of this first approach of our study is the 12-year dataset utilized as defined by hotspot activity. This could be particularly limiting in a region such as the NE, where more data under extreme DR conditions (e.g., El Niño and La Niña events) might be required for a deeper understanding of drought and fire occurrence relationships.

\section{Autoregressive integrated moving average (ARIMA) modeling of DR}

DR could be successfully modeled with acceptable accuracies for most vegetation types by means of ARIMA, similar to works that have utilized these techniques for forecasting fire risk indices in other countries (e.g., Huesca et al. 2014).

It can be seen that Tropical Forests were among the models with a lower performance, perhaps due to the 
lower degree of variation observed in those more humid ecosystems.

DR underestimation occurred on some extreme drought years for some vegetation types. This could be caused by the limitations inherent to the time length of the dataset, limited by the 12 years of available satellite information, for which only some years of extreme drought conditions are present. Continued monitoring of fire risk under varying drought conditions might improve the ability of these initial models to account for extreme events. In addition, a joint consideration of ENSO indices might help improve forecast of extreme drought events and associated fire risk. The ARIMA models for forecasting NDVI-based relative greenness developed in this manuscript could be coupled with gridded weather forecasts for fire risk forecasting (e.g., Roads et al. 2003; Roads et al. 2005) in future works.

\section{Conclusions}

This study represents substantial progress toward developing a system for prediction of fire occurrence risk based on temporal trends in fire density and drought. Temporal trends were measured by a satellite fuel dryness index, dead ratio (DR), in different types of vegetation and regions in Mexico, at a national scale, with a monthly temporal resolution, for the period 2003 to 2014. DR trends varied by vegetation type and region, with drier fuel conditions measured in the most arid type of fuels and regions. Furthermore, significant relationships were found relating monthly fire density and DR for the analyzed vegetation types and regions in the period of study. In addition, we obtained preliminary seasonal autoregressive integrated moving average models for prediction of monthly DR values that might be incorporated into future fire risk forecast operational tools. While these initial results suggest that there is potential for the indices utilized to capture the variations in temporal trends of fuel dryness and their impact on fire occurrence in the country, a longer time period of monitoring will be required for improving our understanding of long-term climatic effects, such as El Niño and La Niña impact, on drought and associated fire risk in the country.

Future work, in the frame of the CONAFOR-CONACYT project for the development of an operational fire risk system in Mexico, will explore temporal trends of fire occurrence with satellite- and weather-based indices of fuel greenness at finer temporal resolutions. Our future studies within this project will also focus on the consideration of spatial patterns of fire density as related to weather, fuels, and human factors (e.g., distance to roads, population, agriculture) for further understanding of the spatial-temporal patterns of fire in Mexico.

\section{Additional files}

Additional file 1: Observed monthly Dead Ratio (DR; upper lines, right axis) and Fire Density Index values (FDI; lower lines, left axis) by vegetation type and region in Mexico for Deciduous Tropical Forest (a) and Perennial Tropical Forest, (b) in the period 2003 to 2014. NW: Northwest region, NE: Northeast region, C: Center region, and S: South region (X). (PDF $486 \mathrm{~kb}$ )

Additional file 2: Observed monthly Dead Ratio (DR; upper lines, right axis) and Fire Density Index values (FDl; lower lines, left axis) by vegetation type and region in Mexico for Shrubby Secondary Vegetation (a) and Arborous Secondary Vegetation, (b) in the period 2003 to 2014. NW: Northwest region, NE: Northeast region, C: Center region, and S: South region (X). (PDF $313 \mathrm{~kb}$ )

Additional file 3: Observed monthly Dead Ratio (DR; upper lines, right axis) and Fire Density Index values (FDl; lower lines, left axis) by vegetation type and region in Mexico for Pastureland, in the period 2003 to 2014. NW: Northwest region, NE: Northeast region, C: Center region, and S: South region (X). (PDF $322 \mathrm{~kb}$ )

\section{Acknowledgements}

We want to thank CONABIO's personnel for providing us access to the MODIS active fire data for Mexico for the period of study. We want to thank CONAFOR's personnel, in particular E. Cruz Castañaeda, A. Nolasco, Y. Coutiño Estrada, C. Robles, and A. Jimenez Flores, for their support in the development and implementation of the Forest Fire Danger Prediction System for Mexico.

\section{Authors' contributions}

DJV-N, MGN-M, EC-F, PML-S, JJC-R, JGÁ-G, and ADR-G performed the statistical analysis. JB-R programmed the code for the daily Fuel Dryness Index automated calculation and for the extraction of FDI values to the daily fire hotspots. MIC-L, MC, and RR calculated daily 100-hour moisture content and 10-day NDVI composites from satellite information from CONABIO. DJV-N, EA-C, AG-C, EM-A, $C L-S, E J, S A-P, C C-M, D P-S$, and EJ-P wrote and reviewed the manuscript. All authors read and approved the final manuscript.

\section{Funding}

Funding for this work was provided by CONAFOR-CONACYT Project 252620 "Development of a Fire Danger System for Mexico." This work was also cofinanced by the Instituto Nacional de Investigación y Tecnología Agraria y Alimentaria and European Social Fund (Dr. E. Jiménez grant).

\section{Availability of data and materials}

The datasets used or analyzed during the current study are available from the corresponding author on reasonable request.

Ethics approval and consent to participate

Not applicable.

\section{Consent for publication}

Not applicable.

\section{Competing interests}

The authors declare that they have no competing interests.

\section{Author details}

${ }^{1}$ Facultad de Ciencias Forestales, Universidad Juárez del Estado de Durango, Río Papaloapan y Bulevard, Durango Sin Numero Colonia Valle del Sur, CP 34120 Durango, Mexico. ${ }^{2}$ Instituto de Silvicultura e Industria de la madera, Universidad Juárez del Estado de Durango, Boulevard del Guadiana 501, Ciudad Universitaria, Torre de Investigación, 34120 Durango, Mexico. ${ }^{3}$ Comisión Nacional para el Conocimiento y Uso de la Biodiversidad (CONABIO), Liga Periférico-Insurgentes Sur 4903, Parques del Pedregal, Delegacion Tlalpan, CP 14010 Ciudad de Mexico, Mexico. ${ }^{4}$ School of Environmental and Forest Sciences, University of Washington, Mailbox 352100, University of Washington, Seattle, Washington 98195, USA. ${ }^{5}$ Pacific Southwest Research Station, US Department of Agriculture Forest Service, 4955 Canyon Crest Drive, Riverside, California 92507, USA. ${ }^{6}$ Instituto de 
Investigaciones en Ecosistemas y Sustentabilidad, Universidad Autónoma de México, Antigua Carretera a Pátzcuaro 8701, Sin Nombre, Residencial San José de la Huerta, 58190 Morelia, Michoacan, Mexico. ${ }^{7}$ Centro Universitario de la Costa Sur, Universidad de Guadalajara, Avenida Independencia Nacional 151, Centro, 48900 Autlán de Navarro, Jalisco, Mexico. ${ }^{8}$ Centro de Investigación Forestal-Lourizán, Xunta de Galicia, Carretera de Marín km 3.5, CP 36153 Pontevedra, Spain. 'Departamento de Ingeniería Agroforestal, Universidad de Santiago de Compostela, Escuela Politécnica Superior de Ingeniería, Campus Universitario Sin Numero, 27002 Lugo, Spain.

\section{Received: 25 April 2019 Accepted: 21 May 2019}

\section{Published online: 07 August 2019}

\section{References}

Antonio, X., and E.A. Ellis. 2015. Forest fires and climate correlation in México state: a report based on MODIS. Advances in Remote Sensing 4: 280-286 https://doi.org/10.4236/ars.2015.44023.

Avila-Flores, D., M. Pompa-García, X. Antonio-Nemiga, D.A. Rodríguez-Trejo, E. Vargas-Perez, and J. Santillan-Pérez. 2010b. Driving factors for forest fire occurrence in Durango state of México: a geospatial perspective. Chinese Geographical Science 20: 491-497 https://doi.org/10.1007/s11769-010-0437-x.

Avila-Flores, D., M. Pompa-García, and E. Vargas-Pérez. 2010a. Spatial analysis of fire occurrence in the Durango state. Revista Chapingo. Serie Ciencias Forestales 16 (2): 253-260 https://doi.org/10.5154/r.rchscfa.2009.08.028.

Bates, D.M., and D.G. Watts. 1988. Nonlinear regression analysis and its applications. New York: Wiley https://doi.org/10.1002/9780470316757.

Burgan, R.E., P.L. Andrews, L.S. Bradshaw, C.H. Chase, R.A. Hartford, and D.J. Latham. 1997. Current status of the Wildland Fire Assessment System (WFAS). Fire Management Notes 57 (2): 14-17.

Burgan, R.E., and R.A. Hartford. 1993. Monitoring vegetation greenness with satellite data. USDA Forest Service General Technical Report INT-297. Ogden: USDA Forest Service, Intermountain Forest and Range Experiment Station.

Burgan, R.E., and R.A. Hartford. 1997. Live vegetation moisture calculated from NDVI and used in fire danger rating. In Proceedings of the 13th Conference on Fire and Forest Meteorology, 27-31 October 1997, Lorne, Australia, ed. J. Greenlee, 225-231. Fairfield: International Association for Wildland Fire.

Burgan, R.E., R.A. Hartford, and J.C. Eidenshink. 1996. Using NDVI to assess departure from average greenness and its relation to fire business. USDA Forest Service General Technical Report INT-GTR-333. Ogden: USDA Forest Service, Intermountain Research Station https://doi.org/10.2737/INT-GTR-333.

Burgan, R.E., R.W. Klaver, and J.M. Klaver. 1998. Fuel models and fire potential from satellite and surface observations. International Journal of Wildland Fire 8 (3): 159-170 https://doi.org/10.1071/WF9980159.

Carrillo García, R.L., D.A. Rodríguez Trejo, H. Tchikoué, A.I. Monterroso Rivas, and J. Santillan Pérez. 2012. Análisis espacial de peligro de incendios forestales en Puebla, México. Interciencia 37 (9): 678-683 [In Spanish].

Castañeda Rojas, M.F., A.R. Endara Agramont, M.L. Villers Ruiz, and G. Nava Bernal. 2015. Evaluación forestal y de combustibles en bosques de Pinus hartwegii en el Estado de México según densidades de cobertura y vulnerabilidad a incendios. Madera y Bosques 21 (2): 45-58 [In Spanish] https://doi.org/10. 21829/myb.2015.212444

Castedo, F., M. Barrio, B.R. Parresol, and J.G. Álvarez González. 2005. A stochastic height-diameter model for maritime pine ecoregions in Galicia (northwestern Spain). Annals of Forest Science 62: 455-465 https://doi.org/10.1051/forest: 2005042.

Cerano Paredes, J., J. Villanueva Díaz, and P.Z. Fulé. 2010. Reconstrucción de incendios y su relación con el clima para la reserva Cerro el Mohinora, Chihuahua. Revista Mexicana de Ciencias Forestales 1 (1): 64-76 [In Spanish].

Chuvieco, E., I. Aguado, and P. Dimitrakopoulos. 2004. Conversion of fuel moisture content values to ignition potential for integrated fire danger assessment. Canadian Journal of Forest Research 34: 2284-2293 https://doi. org/10.1139/x04-101.

Chuvieco, E., I. Aguado, M. Yebra, H. Nieto, J. Salas, M.P. Martín, L. Vilar, J. Martínez, S. Martín, P. Ibarra, J. de la Riva, J. Baeza, F. Rodríguez, J.R. Molina, M.A. Herrera, and R. Zamora. 2010. Development of a framework for fire risk assessment using remote sensing and geographic information system technologies. Ecological Modelling 221: 46-58 https://doi.org/10.1016/j.ecolmodel.2008.11.017.

CONAFOR [Comisión Nacional Forestal]. 2011. Evaluación preliminar de incendios en La Sabina y El Bonito, municipios de Múzquiz, Ocampo, Zaragoza y Acuña, del estado de Coahuila. Informe ejecutivo. Zapopan: CONAFOR, SEMARNAT [In Spanish].
Corral-Rivas, J.J., J.G. Álvarez González, A.D. Ruiz, and K. von Gadow. 2004. Compatible height and site index models for five pine species in El Salto, Durango (Mexico). Forest Ecology and Management 201: 145-160 https://doi. org/10.1016/j.foreco.2004.05.060.

Corral-Rivas, J.J., M. Barrio Anta, E. Treviño Garza, and U. Diéguez-Aranda. 2007. Use of stump diameter to estimate diameter at breast height and tree volume, for major pine species in El Salto, Durango (Mexico). Forestry 80 (1): 29-40 https://doi.org/10.1093/forestry/cpl048.

Cortés Montaño, C., P.Z. Fulé, D.A. Falk, J. Villanueva-Díaz, and L.L. Yocom. 2012. Linking old-growth forest composition, structure, fire history, climate and land use in the mountains of northern México. Ecosphere 3 (11): 1-16 https:// doi.org/10.1890/ES12-00161.1.

Cruz-López, M.I. 2007. Sistema de alerta temprana, monitoreo e impacto de los incendios forestales en México y Centroamérica. In Proceedings of the 4th Wildland Fire International Conference, Seville, Spain, 14-17 May 2007, ed. Organismo Autónomo de Parques Nacionales, Ministerio de Medio Ambiente. Madrid: United Nations International Strategy for Disaster Reduction, the Food and Agriculture Organization of the United Nations, and the European Commission [In Spanish].

Deeming, J., J. Lancaster, M. Fosberg, R. Furman, and M. Shroeder. 1972. National fire-danger rating system. USDA Forest Service Research Paper RM-84. Fort Collins: USDA Forest Service, Rocky Mountain Forest and Range Experiment Station.

Deeming, J.E., R.E. Burgan, and J.D. Cohen. 1977. The National Fire-Danger Rating System-1978. USDA Forest Service General Technical Report INT-39. Ogden: USDA Forest Service, Intermountain Forest and Range Experiment Station.

Drury, S.A., and T.T. Veblen. 2008. Spatial and temporal variability in fire occurrence within the Las Bayas Forestry Reserve, Durango, México. Plant Ecology 197: 299-316 https://doi.org/10.1007/s11258-007-9379-5.

ESRI [Environmental Systems Research Institute]. 2011. ArcGIS desktop: release 10. Redlands: Environmental Systems Research Institute.

Fernández-Manso, A., C. Quintano, and O. Fernández-Manso. 2011. Forecast of NDVI in coniferous areas using temporal ARIMA analysis and climatic data at a regional scale. International Journal of Remote Sensing 32: 1595-1617 https://doi.org/10.1080/01431160903586765.

Flannigan, M., B. Stocks, M. Turetsky, and M. Wotton. 2009. Impacts of climate change on fire activity and fire management in the circumboreal forest. Global Change Biology 15: 549-560 https://doi.org/10.1111/j.1365-2486.2008.01660.x.

Flannigan, M.D., B.D. Amiro, K.A. Logan, B.J. Stocks, and B.M. Wotton. 2006. Forest fires and climate change in the 21 st century. Mitigation and Adaptation Strategies for Global Change 11 (4): 847-859.

Flores Garnica, J.G., J.D. Benavides Solorio, and A. Martinez Moreno. 1990. Índices de riesgos de incendio en la sierra de Tapalpa, estado de Jalisco. Revista Ciencia Forestal en México 67 (15): 4-34 [In Spanish].

Fosberg, M.A., and J.E. Deeming. 1971. Derivation of the 1- and 10-hour timelag fuel moisture calculations for fire-danger rating. USDA Forest Service Research Note RM-207. Fort Collins: USDA Forest Service, Rocky Mountain Forest and Range Research Station.

Fulé, P.Z., J. Villanueva-Díaz, and M. Ramos-Gómez. 2005. Fire regime in a conservation reserve in Chihuahua, México. Canadian Journal of Forest Research 35: 320-330 https://doi.org/10.1139/x04-173.

Giglio, L., J. Descloitres, C.O. Justice, and Y.J. Kaufman. 2003. An enhanced contextual fire detection algorithm for MODIS. Remote Sensing of Environment 87: 273-282 https://doi.org/10.1016/S0034-4257(03)00184-6.

Gillett, N.P., A.J. Weaver, F.W. Zwiers, and M.D. Flannigan. 2004. Detecting the effect of climate change on Canadian forest fires. Geophysical Research Letters 31: L18211 https://doi.org/10.1029/2004GL020876.

González-Cabán, A., and D.V. Sandberg. 1989. Fire management and research needs in México. Journal of Forestry 87: 20-26.

Hamilton, J.D. 1994. Time series analysis. Princeton: Princeton University Press.

Hardy, C.C. 2005. Wildfire hazard and risk: problems, definitions, and context. Forest Ecology and Management 211: 73-82 https://doi.org/10.1016/j.foreco. 2005.01.029.

Heyerdahl, E.K., and E. Alvarado. 2003. Influence of climate and land use on historical surface fires in pine-oak forests, Sierra Madre Occidental, Mexico. In Fire and climatic change in temperate ecosystems of the western Americas, ed. T.T. Veblen, W.L. Baker, G. Montenegro, and T.W. Swetnam, 196-217. New York: Springer Verlag https://doi.org/10.1007/0387-21710-X_7.

Holdridge, L. 1996. Ecología basada en zonas de vida. San José: Instituto Interamericano de Cooperación para la Agricultura [In Spanish]. 
Huang, S., D. Price, and S.J. Titus. 2000. Development of ecoregion-based heightdiameter models for white spruce in boreal forests. Forest Ecology and Management 129: 125-141 https://doi.org/10.1016/S0378-1127(99)00151-6.

Huesca, M., J. Litago, S. Merino-de-Miquel, V. Cicuendez-López-Ocaña, and A. Palacios-Orueta. 2014. Modeling and forecasting MODIS-based Fire Potential Index on a pixel basis using time series models. International Journal of Applied Earth Observation and Geoinformation 26: 363-376 https://doi.org/10. 1016/j.jag.2013.09.003.

Huesca, M., J. Litago, A. Palacios-Orueta, F. Montes, A. Sebastián-López, and P. Escribano. 2009. Assessment of forest fire seasonality using MODIS fire potential: a timeseries approach. Agricultural and Forest Meteorology 149: 1946-1955 https://doi.org/10.1016/j.agrformet.2009.06.022.

Huesca, M., A. Palacios-Orueta, F. Montes, A. Sebastián-López, and P. Escribano. 2007. Forest Fire Potential Index for Navarra Autonomic Community (Spain) In Proceedings of the 4th Wildland Fire International Conference, Seville, Spain, 14-17 May 2007, ed. Organismo Autónomo de Parques Nacionales, Ministerio de Medio Ambiente. Madrid: United Nations International Strategy for Disaster Reduction, the Food and Agriculture Organization of the United Nations, and the European Commission.

Hyndman, R. 2016. Package "forecast." https://cran.r-project.org/web/packages/ forecast/forecast.pdf Accessed 11 May 2019.

Ibarra-Montoya, J.L., and F.M. Huerta-Martínez. 2016. Modelado espacial de incendios: una herramienta predictiva para el Bosque La Primavera, Jalisco, México. Revista Ambiente \& Agua 11 (1): 36-51 [In Spanish]. https://doi.org/10. 4136/ambi-agua.1536.

Jardel, E.J., D. Pérez-Salicrup, E. Alvarado, and J.E. Morfín Ríos. 2014. Principios y criterios para el manejo del fuego en ecosistemas forestales: guía de campo. Guadalajara: Comisión Nacional Forestal [In Spanish].

López, A.S., J. San-Miguel-Ayanz, and R.E. Burgan. 2002. Integration of satellite sensor data, fuel type maps and meteorological observations for evaluations of forest fire risk at the pan-European scale. International Journal of Remote Sensing 23 (13): 2713-2719 https://doi.org/10.1080/01431160110107761.

Lozano, F.J., S. Suárez-Seoane, and E. De Luis. 2007. Assessment of several spectral indices derived from multi-temporal Landsat data for fire occurrence probability modelling. Remote Sensing of Environment 107: 533-544 https:// doi.org/10.1016/j.rse.2006.10.001.

Lozano, F.J., S. Suarez-Seoane, and E. De Luis. 2008. A multi-scale approach for modeling fire occurrence probability using satellite data and classification trees: a case study in a mountainous Mediterranean region. Remote Sensing of Environment 112 (3): 708-719 https://doi.org/10.1016/j.rse.2007.06.006.

Manzo-Delgado, L., R. Aguirre-Gómez, and R. Álvarez. 2004. Multitemporal analysis of land surface temperature using NOAA-AVHRR: preliminary relationships between climatic anomalies and forest fires. International Journal of Remote Sensing 25: 4417-4423 https://doi.org/10.1080/01431160412331269643.

Manzo-Delgado, L., S. Sánchez-Colón, and R. Álvarez. 2009. Assessment of seasonal forest fire risk using NOAA-AVHRR: a case study in central Mexico. International Journal of Remote Sensing 30 (19): 4991-5013 https://doi.org/10. 1080/01431160902852796

Martínez-Torres, H.L., A. Castillo, M.I. Ramírez, and D.R. Pérez-Salicrup. 2016. The importance of the traditional fire knowledge system in a subtropical montane socioecosystem in a protected natural area. International Journal of Wildland Fire 25 (9): 911-921 https://doi.org/10.1071/WF15181.

Mavsar, R., A. González-Cabán, and E. Varela. 2013. The state of development of fire management decision support systems in America and Europe. Forest Policy and Economics 29: 45-55 https://doi.org/10.1016/j.forpol. 2012.11.009.

Morfín Ríos, J.E., E. Alvarado Celestino, E.J. Jardel Peláez, R.E. Vihnanek, D.K. Wright, J.M. Michel Fuentes, C.S. Wright, R.D. Ottmar, D.V. Sandberg, and A. Nájera Díaz. 2007. Fotoseries para la cuantificación de combustibles forestales de México: Bosques Montanos Subtropicales de la Sierra Madre del Sur y Bosques Templados y Matorral Submontano del Norte de la Sierra Madre Oriental. Pacific Wildland Fire Sciences Laboratory Special Publication No. 1. Seattle: University of Washington, College of Forest Resources.

Morfin Rios, J.E., E.J. Jardel Peláez, and J.M. Michel Fuentes. 2012. Caracterización y cuantificación de combustibles forestales. Guadalajara: Comisión Nacional Forestal, Universidad de Guadalajara [In Spanish].

Muñoz Robles, C.A., E.J. Treviño Garza, J. Verástegui Chávez, J. Jiménez Pérez, and O.A. Aguirre Calderón. 2005. Desarrollo de un modelo espacial para la evaluación del peligro de incendios forestales en la sierra madre oriental de México. Investigaciones Geográficas 56: 101-117 https://doi.org/10.14350/rig. 30099 [In Spanish].
Návar-Cháidez, J.J., and L.G. Lizárraga-Mendiola. 2013. Hydro-climatic variability and forest fires in Mexico's northern temperate forests. Geofísica Internacional 52: 5-20 https://doi.org/10.1016/S0016-7169(13)71458-2.

Pérez-Verdin, G., M.A. Márquez-Linares, A. Cortes-Ortiz, and M. Salmerón-Macias. 2013a. Patrones de Distribución Espacio Temporal de los Incendios Forestales en el Norte de México. In Memorias del Cuarto Simposio Internacional Sobre Políticas, Planificación y Economía de los Incendios Forestales: Cambio Climático e Incendios Forestales, USDA Forest Service General Technical Report PSW-GTR-245. Technical coordination by González-Cabán, 221-231. Albany: USDA Forest Service, Pacific Southwest Research Station [In Spanish]. https://doi.org/10.2737/PSW-GTR-245ES.

Pérez-Verdin, G., M.A. Márquez-Linares, A. Cortés-Ortiz, and M. Salmerón-Macías. 2013b. Análisis espacio-temporal de la ocurrencia de incendios forestales en Durango, México. Madera y Bosques 19 (2): 37-58 https://doi.org/10.21829/ myb.2013.192339 [In Spanish]

Pérez-Verdin, G., M.A. Marquez-Linares, and M. Salmeron-Macias. 2014. Spatial heterogeneity of factors influencing forest fires size in northern México. Journal of Forestry Research 25 (2): 291-300 https:/doi.org/10.1007/s11676-014-0460-3.

Pompa-García, M., J. Camarero, D.A. Rodríguez-Trejo, and D.J. Vega-Nieva. 2018. Drought and spatiotemporal variability of forest fires across Mexico. Chinese Geographical Science 28 (1): 25-37 https://doi.org/10.1007/s11769-017-0928-0.

Pompa-García, M., and P. Hernández González. 2012. Determinación de la tendencia espacial de los puntos de calor como estrategia para monitorear los incendios forestales en Durango, México. Bosque (Valdivia) 33(1): 63-68. https://doi.org/10.4067/S0717-92002012000100007 [In Spanish].

Preisler, H.K., D. Brillinger, R.E. Burgan, and J.W. Benoit. 2004. Probability based models for estimation of wildfire risk. International Journal of Wildland Fire 13: 133-142 https://doi.org/10.1071/WF02061.

Preisler, H.K., R.E. Burgan, J.C. Eidenshink, J.M. Klaver, and R.W. Klaver. 2009. Forecasting distributions of large federal-lands fires utilizing satellite and gridded weather information. International Journal of Wildland Fire 18: 508 516 https://doi.org/10.1071/WF08032.

Preisler, H.K., S.C. Chen, F. Fujioka, J.W. Benoit, and A.L. Westerling. 2008. Wildland fire probabilities estimated from weather model-deduced monthly mean fire danger indices. International Journal of Wildland Fire 17: 305-316 https://doi. org/10.1071/WF06162.

Preisler, H.K., J.C. Eidenshink, S. Howard, and R.E. Burgan. 2015. Forecasting distribution of numbers of large fires. In Proceedings of the large wildland fires conference, 19-23 May, 2014, Missoula, Montana, USA. USDA Forest Service Proceedings RMRS-P-73, ed. R.E. Keane, M. Jolly, R. Parsons, and K. Riley, 181-187. Fort Collins: USDA Forest Service, Rocky Mountain research Station.

Preisler, H.K., and A.L. Westerling. 2007. Statistical model for forecasting monthly large wildfire events in western United States. Journal of Applied Meteorology and Climatology 46: 1020-1030 https://doi.org/10.1175/JAM2513.1.

Preisler, H.K., A.L. Westerling, K.M. Gebert, F. Munoz-Arriola, and T.P. Holmes. 2011. Spatially explicit forecasts of large wildland fire probability and suppression costs for California. International Journal of Wildland Fire 20: 508-517 https:// doi.org/10.1071/WF09087.

R Core Team. 2016. R: a language and environment for statistical computing. Vienna: R Foundation for Statistical Computing https://www.R-project.org/.

Riley, K.L., J.T. Abatzoglou, I.C. Grenfell, A.E. Klene, and F.A. Heinsch. 2013. The relationship of large fire occurrence with drought and fire danger indices in the western USA, 1984-2008: the role of temporal scale. International Journal of Wildland Fire 22: 894-909 https://doi.org/10.1071/WF12149.

Roads, J.O., S.C. Chen, and M. Kanamitsu. 2003. US regional climate simulations and seasonal forecasts. Journal of Geophysical Research 108: 8606 https://doi. org/10.1029/2002JD002232.

Roads, J.O., F. Fujioka, S.C. Chen, and R.E. Burgan. 2005. Seasonal fire danger forecasts for the USA. International Journal of Wildland Fire 14 (1): 18 https:// doi.org/10.1071/WF03052.

Rodríguez y Silva, F., J.R. Molina Martínez, and A. González-Cabán. 2014. A methodology for determining operational priorities for prevention and suppression of wildland fires. International Journal of Wildland Fire 24 (3): 544-554 https://doi.org/10.1071/WF13063.

Rodríguez-Trejo, D.A. 2008. Fire regimes, fire ecology and fire management in México. AMBIO: A Journal of the Human Environment 37 (7): 548-556 https:// doi.org/10.1579/0044-7447-37.7.548.

Rodríguez-Trejo, D.A. 2015. Incendios de vegetación: su ecología, manejo e historia. México. Chapingo: Colegio de Post Graduados [In Spanish].

Rodríguez-Trejo, D.A., and P.Z. Fulé. 2003. Fire ecology of Mexican pines and fire management proposal. International Journal of Wildland Fire 12: 23-37 https://doi.org/10.1071/WF02040. 
Rodríguez-Trejo, D.A., H. Ramírez, H. Tchikoué, and J. Santillán. 2008. Factores que inciden en la siniestralidad de los incendios forestales. Ciencia Forestal 33: 37-58. [In Spanish].

Rodríguez-Trejo, D.A., H. Tchikoué, C. Cíntora, R. Contreras, and A. de la Rosa. 2011. Combustibles forestales, peligro de incendio y áreas prioritarias de protección en las zonas afectadas por el huracán Dean. Agrociencia 45: 593608. [In Spanish]

Román-Cuesta, R.M., M. Gracia, and J. Retana. 2003. Environmental and human factors influencing fire trends in ENSO and non-ENSO years in tropical Mexico. Ecological Applications 13 (4): 1177-1192 https://doi.org/10.1890/ 1051-0761(2003)13[1177:EAHFIF]2.0.CO;2.

Román-Cuesta, R.M., and J.V. Martínez. 2006. Effectiveness of protected areas in mitigating fire within their boundaries: case study of Chiapas, México. Conservation Biology 20 (4): 1074-1086 https://doi.org/10.1111/j.1523-1739. 2006.00478.x

Román-Cuesta, R.M., J. Retana, and M. Gracia. 2004. Fire trends in tropical Mexico: a case study of Chiapas. Journal of Forestry 102: 26-48.

SAS Institute Inc. 2009. Base SAS 9.2 procedures guide. Cary: SAS Institute Inc.

Seager, R., M. Ting, M. Davis, M. Cane, N. Naik, J. Nakamura, C. Li, E. Cook, and D. W. Stahle. 2009. Mexican drought: an observational modeling and tree ring study of variability and climate change. Atmosfera 22: 1-31.

Seager, R., M. Ting, I. Held, Y. Kushnir, J. Lu, G. Vecchi, H.P. Huang, N. Harnik, A. Leetmaa, N.C. Lau, C. Li, J. Velez, and N. Naik. 2007. Model projections of an imminent transition to a more arid climate in southwestern North America. Science 316: 1181-1184 https://doi.org/10.1126/science.1139601.

Sebastian-Lopez, A., J. San-Miguel-Ayanz, and R.E. Burgan. 2002. Integration of satellite sensor data, fuel type maps and meteorological observations for evaluation of forest fire risk at the pan-European scale. International Journal of Remote Sensing 23 (13): 2713-2719 https://doi.org/10.1080/ 01431160110107761.

Sepúlveda, B.J., R. Meza, C.W. Zúñiga, G. Solìs, and E.M. Olguín. 2001. SIG para determinar riesgo de incendios forestales en el noroeste de Mexico. México City: Instituto Nacional de Investigaciones Forestales y Agropecuarias [In Spanish].

Setzer, A.W., and R.A. Sismanoglu. 2012. Risco de fogo: metodologia do cálculo-descrição sucinta da versão 9. Sao Paulo: Instituto Nacional de Pesquisas Espaciais [In Spanish].

Skinner, C.N., J.H. Burk, M.G. Barbourt, E. Franco-Vizcaíno, and S.L. Stephens. 2008. Influences of climate on fire regimes in montane forests of north-western Mexico. Journal of Biogeography 35: 1436-1451 https://doi.org/10.1111/j.13652699.2008.01893.x.

Van Wagner, C.E. 1987. Development and structure of the Canadian Forest Fire Weather Index System. Canadian Forestry Service, Forestry Technical Report 35. Ottawa: Canadian Forest Service.

Vega-Nieva, D.J., J. Briseño, N.A. Monjarás-Vega, C.I. Briones-Herrera, F. FloresMedina, J.J. Corral-Rivas, M.G. Nava, E. Calleros, P.M. López-Serrano, I. Cruz, M. Cuahtle, R. Ressl, E. Alvarado, A. González-Cabán, H.K. Preisler, W. M. Jolly, R.E. Burgan, A. Setzer, F. Morelli, D. Pérez-Salicrup, E. Jardel, E. Jiménez, J.G. Álvarez-González, S. Arellano-Pérez, and A.D. Ruiz-González. 2019a. The Forest Fire Danger Prediction System of Mexico. In Proceedings of the 6th international fire behavior and fuels conference, 29 April to 3 May 2019, Albuquerque, New Mexico, USA. Missoula: International Association of Wildland Fire.

Vega-Nieva, D.J., J. Briseño-Reyes, M.G. Nava-Miranda, E. Calleros-Flores, P.M López-Serrano, J.J. Corral-Rivas, E. Montiel-Antuna, M.I. Cruz-López, M. Cuahutle, R. Ressl, E. Alvarado-Celestino, A. González-Cabán, E. Jiménez, J.G. Álvarez-González, A.D. Ruiz-González, R.E. Burgan, and H.K. Preisler. 2018. Developing models to predict the number of fire hotspots from an accumulated fuel dryness index by vegetation type and region in Mexico. Forests 9: 190 https://doi.org/10.3390/f9040190.

Vega-Nieva, D.J., M.G. Nava-Miranda, E. Calleros-Flores, P.M. Lopez-Serrano, J. Briseño-Reyes, F. Flores-Medina, C.A. Lopez-Sanchez, J.J. Corral-Rivas, A. Gonzalez-Cabán, E. Alvarado-Celestino, I. Cruz, M. Cuahlte, R. Ressl, A. Setzer, F. Morelli, D. Perez-Salicrup, E. Jardel-Pelaez, C. Cortes-Montaño, J.A. Vega, and E. Jiménez. 2019b. Development of a forest fire danger system for Mexico. In Proceedings of the fifth international symposium on fire economics, planning, and policy: ecosystem services and wildfires. USDA Forest Service General Technical Report PSW-GTR-261. Technical editing by A. González-Cabán and J.J. Sánchez, 38-47. Albany: USDA Forest Service, Pacific Southwest Research Station.

Villers-Ruiz, M.L., E. Chuvieco, and I. Aguado. 2012. Aplicación del Índice Meteorológico de Incendios Canadiense en un Parque Nacional del centro de México. Revista Mexicana de Ciencias Forestales 3 (11): 25-40 https://doi. org/10.29298/rmcf.v3i11.515. [In Spanish].

Wong González, J.C., and M.L. Villers Ruiz. 2007. Evaluación de combustibles y su disponibilidad en incendios forestales: un estudio en el Parque Nacional La Malinche. Investigaciones Geográficas 62: 87-103 https://doi.org/10.14350/rig. 29971 [In Spanish].

Woolford, D.G., C.B. Dean, D.L. Martell, J. Cao, and B.M. Wotton. 2013. Lightningcaused forest fire risk in northwestern Ontario, Canada is increasing and associated with anomalies in fire-weather. Environmetrics 25 (6): 406-416 https://doi.org/10.1002/env.2278.

Wotton, B.M., D.L. Martell, and K.A. Logan. 2003. Climate change and human caused forest fire occurrence in Ontario. Climatic Change 60: 275-295 https:// doi.org/10.1023/A:1026075919710.

Yebra, M., E. Chuvieco, and D. Riaño. 2008. Estimation of live fuel moisture content from MODIS images for fire risk assessment. Agricultural and Forest Meteorology 148: 523-536 https://doi.org/10.1016/j.agrformet.2007.12.005.

Yebra, M., P.E. Dennison, E. Chuvieco, D. Riaño, P. Zylstra, R. Hunt, F.M. Danson, Y. Qi, and S. Jurdao. 2013. A global review of remote sensing of live fuel moisture content for fire danger assessment: moving towards operational products. Remote Sensing of Environment 136: 455-468 https://doi.org/10. 1016/j.rse.2013.05.029.

Yocom, L.L., and P.Z. Fulé. 2012. Human and climate influences on frequent fire in a high-elevation tropical forest. Journal of Applied Ecology 49 (6): 13561364 https://doi.org/10.1111/j.1365-2664.2012.02216.x.

Yocom, L.L., P.Z. Fulé, P.M. Brown, J. Cerano-Paredes, J. Villanueva, E. Cornejo Oviedo, and D.A. Falk. 2010. El Niño-Southern Oscillation effect on a fire regime in northeastern Mexico has changed over time. Ecology 91: 16601671 https://doi.org/10.1890/09-0845.1.

Yocom, L.L., P.Z. Fulé, D. Falk, C. Garcia-Dominguez, E. Cornejo-Oviedo, P.M. Brown, J. Villanueva-Díaz, J. Cerano, and C. Cortés Montaño. 2014. Fine-scale factors influence fire regimes in mixed-conifer forests on three high mountains in México. International Journal of Wildland Fire 23 (7): 959-968 https://doi.org/10.1071/WF13214.

Zhang, L., L. Peng, S. Huang, and X. Zhou. 2002. Development and evaluation of ecoregion-based tree height-diameter models for jack pine in Ontario. The Forestry Chronicle 78: 530-538. https://doi.org/10.5558/tfc78530-4.

Zúñiga-Vásquez, J.M., D. Cisneros-González, and M. Pompa-García. 2017a. Drought regulates the burned forest areas in Mexico: the case of 2011, a record year. Geocarto International. https://doi.org/10.1080/10106049.2017.1415986.

Zúñiga-Vásquez, J.M., D. Cisneros-González, M. Pompa-García, D.A. RodríguezTrejo, and G. Pérez-Verdín. 2017b. Spatial modeling of forest fires in Mexico: an integration of two data sources. Bosque (Valdivia) 38 (3): 563-574 https:// doi.org/10.4067/S0717-92002017000300014.

\section{Publisher's Note}

Springer Nature remains neutral with regard to jurisdictional claims in published maps and institutional affiliations.

\section{Submit your manuscript to a SpringerOpen ${ }^{\circ}$ journal and benefit from:}

- Convenient online submission

- Rigorous peer review

- Open access: articles freely available online

- High visibility within the field

- Retaining the copyright to your article

Submit your next manuscript at $\boldsymbol{\nabla}$ springeropen.com 